CHILDREN'S RIGHTS IN THE SOUTH-AFRICAN CONSTITUTION

ISSN 1727-3781

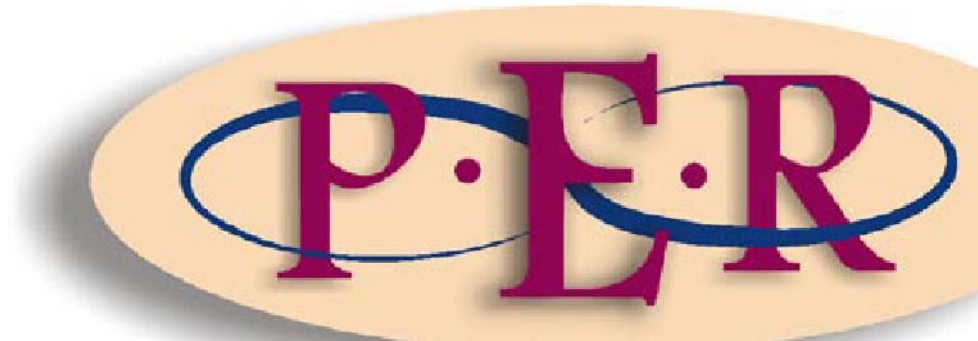

2003 VOLUME 6 No 1 


\section{CHILDREN'S RIGHTS IN THE SOUTH-AFRICAN CONSTITUTION}

Prof JA Robinson

\section{$1 \quad$ INTRODUCTION}

It is a truism that both the history of a country and its peoples and the dispensation the country aspires to be, is to some degree reflected in its Constitution. South Africa is certainly no exception. The constitutional dispensation that came into effect in South Africa on the 27th April 1994 was designed to innovate social, political and legal structures that would be radically different from those of the country's past history. ${ }^{1}$ The Constitution not only recognises the injustices of the past, but also depicts the new South Africa as an open and democratic society based on human dignity, equality and

freedom. ${ }^{2}$ To this end the constitutional Bill of Rights provides the legally enforceable backing. In the new dispensation any institution associated with the discrimination and repression practices of apartheid South Africa is

* This contribution will also be published in the series Forum Juris Internationalis presented by the Faculty of Law, Justus Liebig Universität, Gießen, Germany.

1 The Constitution of the Republic of South Africa 200 of 1993 (hereafter referred to as the Interim Constitution) came into force on the 27th April 1994. It effected radical changes in the sense that henceforth the franchise and associated political and civil rights would be accorded to all citizens without racial qualification and the doctrine of parliamentary sovereignty was now replaced by the doctrine of constitutional supremacy. The Interim Constitution was formally adopted as an Act of the pre-democratic Tricameral Parliament and was only meant to be a transitional Constitution. One of its principal purposes was to set out the procedures for the negotiation and drafting of a final Constitution. The Constitution of the Republic of South Africa 108 of 1996 (hereafter referred to as the Constitution) completes the negotiated revolution. The Constitution was drafted and adopted by an elected Constitutional Assembly which had been given two years to produce a constitution that conformed to 34 constitutional principles that had been agreed upon during the pre-1993 political negotiations. In Ex parte Chairperson of the Constitutional Assembly: in re Certification of the Constitution of the Republic of South Africa 1996 (First Certification judgment) 19964 SA 744 (CC) the Constitutional Court refused to certify that the Constitution conformed to the said principles and it was only in the so-called Second Certification judgment 1997 2 SA 97 (CC) that the Constitutional Court was prepared to find that the text was consistent with the constitutional principles. The Constitution was signed into law by President Nelson Mandela at Sharpeville on 4 February 1997. See De Waal, Currie \& Erasmus The Bill of Rights Handbook (4th ed) ch 1 (hereafter referred to as De Waal et al).

2 In the preamble to the Constitution it is specifically stated that the injustices of the country's past are recognised and that the Constitution is adopted as the supreme law of the country so as to heal the divisions of the past and to establish a society based on democratic values, social justice and fundamental human rights. 
incompatible with the values embodied in the kind of society the country now aspires to be.

Institutionalised discrimination constituted a major characteristic of the political history of South Africa. It may perhaps even have been the most decisive impetus for the country's radical transformation. The principle of equal treatment and non-discrimination has consequently been afforded a special place in the Constitution. Racial discrimination and sex discrimination, as well as other inequalities, were inscribed in the social fabric of apartheid South Africa. Children too, were in many respects defenceless victims of such discriminatory practices. The degradation imposed upon, and profound humiliation suffered by, children's parents under the apartheid system, had a severe impact on them. Small wonder then that the principle of equal treatment and nondiscrimination has been afforded special importance in the Constitution.

The transformation effected by the constitutional dispensation was radical. In fact, eminent scholars from the United States convey that South Africa is increasingly establishing itself at the centre of a transnational exchange of ideas about the rule of law and human rights, and that human rights scholars around the world can ill afford not to pay attention to the developments in the country. In this regard reference is made to the fact, inter alia, that South Africa is the first state to expressly prohibit discrimination on grounds of sexual orientation in its Constitution. ${ }^{5}$ This development caused normative ripple effects around the globe.

3 Van der Vyver 'Constitutional Protection of Children and Young Persons' in Robinson The Law of Children and Young Persons in South Africa 267 (hereafter referred to as Van der Vyver).

4 Scott \& Alston 'Adjudicating Constitutional Priorities in a Transnational Context: A Comment on Soobramoney's Legacy and Grootboom's Promise' in 2000 South African Journal of Human Rights 211.

5 S 9 of the Constitution expressly forbids unfair discrimination, directly or indirectly, on, inter alia, sexual orientation and sex. Without entering into debate on this issue, it may be noted, though, that the status of samesex relationships is currently a hotly debated issue in South Africa. See Langemaat $v$ Minister of Safety and Security 19922 All SA 259 (T); National Coalition for Gay and Lesbian Equality v Minister of Home Affairs 1999 3 SA 173(C) ; Du Toit v Minister of Welfare and Population Development and Others (Lesbian and Gay Equality Project as Amicus Curiae) 20032 SA 198 (CC). In a yet unreported case, J\&B v Director General: Department of Home Affairs, 
In order to fathom the impact of the Constitution upon the rights of children, a general overview of constitutional principles and provisions necessary for the comprehension of the rights of children in the Constitution will be given. Thereafter the rights of children expressly mentioned in the Constitution will be addressed. The equal protection and non-discrimination provisions will also be addressed, albeit only indirectly.

\section{CONSTITUTIONAL PRINCIPLES RELATING TO THE RIGHTS OF CHILDREN}

\subsection{The application of the Constitution}

From the provisions of section 8(1) it is clear that the Bill of Rights, true to nature, binds all organs of state. The sub-section reads that the Bill 'applies to all law, and binds the legislature, the executive, the judiciary and all organs of state.' As this provision is selfexplanatory, no further attention will be paid to it except to indicate, however, that 'law' in these sections is translated in the Afrikaans version of the Constitution as 'regsvoorskrif' ('Rechtsvorschrift'). What is designated by this provision, therefore, is that 'law' means positive law which includes statutory law, common law and customary law in contradistinction to where law is translated as 'wet' ('Gesetz').

Sections 8(2) and (3) provide for the application of the Bill also in private law matters. As such, the phraseology in which the horizontal application of provisions of the Bill is couched, is juxtaposed with the developmental function of the court in respect of the common law. Section 8(2) and (3) provides as follows in this regard:

Constitutional Case No 46/02 decided on 28 March 2003, the Constitutional Court held that comprehensive legislation regularising relationships between gay and lesbian persons is necessary since it is unsatisfactory for courts to grant piecemeal relief to the gay and lesbian community as and when aspects of their relationships are found to be prejudiced by unconstitutional legislation. Contrary to the position in Germany where the argument revolved around the provisions of art 6 I of the Grundgesetz which protect marriage qua institution when the constitutionality of the Gesetz zur Beendigung der Diskriminierung gleichgeschlechtlicher Gemeinschaften:Lebenspartnerschaften of 16 February 2002 was at issue, the debate in South Africa focuses on the provisions of $s 9$ of the Constitution which prohibits unfair discrimination. For further discussion of the relevance of same-sex relationships to the rights of children, see text accompanying $n 65$ infra. Van der Vyver (n 3) 268 n 23. 
(2) A provision of the Bill of Rights binds a natural or a juristic person if, and to the extent that, it is applicable, taking into account the nature of the right and the nature of any duty imposed by the right.

(3) When applying a provision of the Bill of Rights to a natural or juristic person in terms of subsection (2), a court -

(a) in order to give effect to a right in the Bill, must apply, or if necessary develop, the common law to the extent that legislation does not give effect to that right; and

(b) may develop rules of the common law to limit the right, provided that the limitation is in accordance with section 36(1).

From the outset above, it is clear that in contradistinction to section 8(1), natural and juristic persons are only bound by the Bill of Rights to the extent that a provision of the Bill is applicable in view of the nature of the right and the duty imposed. Questions concerning the horizontal application of the Bill can therefore not be determined a priori and in the abstract. In fact, from the very wording of section 8(3) it appears that whether a provision of the Bill applies horizontally, will depend on the nature of the private conduct in question and the circumstances of the particular case. The extent to which a provision is applicable can only be determined by reference to the context within which it is sought to be relied upon. ${ }^{8}$ If, however, the provisions of section $8(2)$ do find application, the duty to uphold, endure or execute the right

8 ibid. De Waal et al provide the following examples to illustrate the argument: The right of every arrested person to be informed promptly of the right to remain silent is of a nature that makes it generally inapplicable to private arrests. There is, however, no reason why a private security officer who knows of this constitutional right, should not observe it. Conversely, the right to assemble peacefully and unarmed generally applies on the horizontal level. The right to assemble in, for example, shopping malls and on the property of an employer is therefore guaranteed. But in some circumstances it may be inappropriate to apply the right horizontally. For example, it is unlikely that the right to assemble can be relied on to justify demonstrations in, or in front of, someone's private home. 
vests in a natural or juristic person similarly than is the position with regard to organs within the State structure as set out in section 8(1).

The purpose of a provision is an important consideration to determine whether it is applicable to private conduct or not. ${ }^{10}$ By the same token, the nature of any duty imposed by the right must also be taken into account. Private or juristic persons are often driven primarily by a concern for themselves while the State, on the other hand, should rather be motivated by a concern for the well-being of society as a whole. The application of the Bill should therefore not undermine private autonomy to the same extent that it places restrictions on the sovereignty of parliament.

Section 8(2) applies to all instances where the regulatory law, which either affords legality to the decision taken or act performed, or which prohibits such conduct through private law proscriptions or sanctions, is part of the common law. A court is therefore charged with the obligation of considering the permissive or proscriptive rule applicable to conduct of the duty-bound person with two primary questions in mind:

- $\quad$ does the concerned rule of the common law in any way frustrate the constitutionally protected right implicated by the decision or act of the duty bound subject?

- does the concerned rule of the common law permit limitations of the constitutionally protected right which do not comply with the demands of the limitations provision of the Constitution?

If the answer to either of these questions is in the affirmative, a court will be under an obligation to 'develop' the common law in order to give effect to the

9 Van der Vyver (n 3) 270.

10 De Waal et al (n 1) 56.

11 ibid.

12 It would appear that in the following instances there will be no Drittwirkung: situations with regard to citizenship rights; the right to just administrative action; the rights of detained, arrested and accused persons generally. In the following instances it can be said that the nature of duties imposed by the right to have legislative and other measures taken would (normally) result in them not being applicable to private conduct: the rights to protect the environment, the right to housing, the right to health care, food, water and social security, and to education. 
constitutionally protected right and/or to bring the limitation of that right as sanctioned by the common law in conformity with the limitation demands of the Constitution. ${ }^{13}$ It is also clear that development of the common law in terms of section 8(2) entitles a court to read constitutional rights into the common law which the common law would otherwise not have protected. It may also rewrite common law limitations pertaining to a particular right which

The form of application in s 8(2) reflects the so-called indirect application of the Bill of Rights. In this instance a dispute is resolved by interpreting a statute or developing the common law so as to promote the spirit, purport and objects of the Bill through the operation of ordinary law. When the Bill is directly applied, however, the question is whether there is any inconsistency between the Bill and the law or conduct in question. If so, such law or conduct unjustifiably violates the Bill and a remedy provided for by the Constitution will be given to the applicant. See De Waal et al (n 1) 167. Remedies flowing from a direct application of the Bill to law and conduct are provided for by sections 38, 172(1), 8(3) and 39(2). These sections provide as follows: S 38: Anyone listed in this section has the right to approach a competent court, alleging that a right in the Bill of Rights has been infringed or threatened, and the court may grant appropriate relief, including a declaration of rights. S 172(1): When deciding a constitutional matter within its power, a court -

(a) must declare that any law or conduct that is inconsistent with the Constitution is invalid to the extent of its inconsistency; and

(b) may make an order that is just and equitable, including -

(i) an order limiting the retrospective effect of the declaration of invalidity; and

(ii) an order suspending the declaration of invalidity for any period and on any conditions, to allow the competent authority to correct the defect.

S 8(3) has been referred to supra.

S 39(2) provides as follows: When interpreting any legislation, and when developing the common law or customary law, every court, tribunal or forum must promote the spirit, purport and objects of the Bill of Rights. Prima facie there appears to be an overlap between the provisions of ss 39(2) and 8(3). On closer scrutiny, however, it is clear that there is a marked difference in the sense that $s$ 8(3) establishes a law creating power, whereas the competence vested in a court by s 39(2) in regard to the common law is one of applying its normal power of interpretation in favorum libertatis with the spirit, purport and objects of the Constitution as a substantive directive. Van der Vyver (n 3) 274. Van der Vyver warns, though, that the distinction between law creation in terms of s 8(3) and development through interpretation pursuant to s 39(2) is difficult to define with any degree of precision. The language of $s$ 8(3) indicates the power of the court to add to the common law provisions that would afford protection of constitutionally defined rights which the common law as such would otherwise not have provided. It furthermore adds to the common law limitations of constitutionally protected rights in their application to natural and juristic persons which will conform with the limitation provisions of the Constitution in all instances where the common law confinement of such rights falls short of the constitutional limitation conditions and requirements. The provisions of $s$ 172(2)(a) of the Constitution should also be borne in mind. This section provides that the Supreme Court of Appeal, a High Court or a court of similar status may make an order concerning the constitutional validity of an Act of Parliament. However, such an order will have no force unless it is confirmed by the Constitutional Court. 
is now also protected by the Constitution so as to equate those limitations with the constitutional conditions for, and requirements of, such limitations.

\subsection{The limitation of constitutionally protected rights}

Section 36(2) provides that limitation of a constitutionally protected right must comply with the prescriptions of section 36(1) or with the dictates of any other provision of the Constitution. In terms of section 36(1) the limitation of a constitutionally protected right must adhere to the following requirements:

- $\quad$ the limitation must be sanctioned by law of general application;

- $\quad$ the limitation must be reasonable;

- $\quad$ the limitation must be justifiable in an open and democratic society based on human dignity, equality and freedom taking into account all relevant factors, including the nature of the right, the importance of the purpose of the limitation, the nature and extent of the limitation, the relation between the limitation and its purpose, and also less restrictive means to achieve the purpose.

It is to be noted that 'law of general application' reflects a broad definition of law, including limitations sanctioned by statutory provisions and the common law. The requirement of reasonableness was held to mean that a law or action limiting a right must have a reasonable goal and also that the means for achieving that goal must be reasonable. ${ }^{16}$ However, in S v Makwanyane and

14 Van der Vyver (n 3) 271. Van der Vyver points out that courts are given law-creating powers which by far exceed those exercised previously by the High Court in respect of the common law. The fact that implementation of s 8(3) powers amounts to the courts' usurping the function of the legislature and as such violates the separation of powers which constitutes a salient component of the new constitutional dispensation, is, however, of no relevance after the decision of the Constitutional Court in In re Certification of the Amended text of the Constitution of the Republic of South Africa, 199619971 BCLR 1 (CC) (see n 1 supra.). Having endorsed the revised Constitution, the Constitutional Court afforded incontestable sanction to these powers. It is furthermore important to note that whereas in the past principles of natural justice served as criterion of the judicial developmental function, the courts must now look to the Constitution to find the norm of rights protection, and of the limitation of rights that must be incorporated into the common law.

15 Van der Vyver (n 3) 277.

16 See Coetzee v Government of the Republic of South Africa 19954 SA 631 (CC). 


\section{Another $^{17}$ the Constitutional Court sounded a more cautious approach to this requirement.}

The limitation of constitutional rights for a purpose that is reasonable and necessary in a democratic society involves the weighing up of competing values, and ultimately an assessment based on proportionality. ... The fact that different rights have different implications for democracy and, in the case of our Constitution, for 'an open and democratic society based on freedom and equality', means that there is no absolute standard which can be laid down for determining reasonableness and necessity. Principles can be established, but the application of those principles to particular circumstances can only be done on a case-by-case basis. This is inherent in the requirement of proportionality, which calls for the balancing of different interests. In the balancing process the relevant considerations will include the nature of the right that is limited and its importance to an open and democratic society based on freedom and equality; the purpose for which the right is limited and the importance of that purpose to such a society; the extent of the limitation, its efficacy and, particularly where the limitation has to be necessary, whether the desired ends could reasonably be achieved through other means less damaging to the right in question. In the process regard must be had to the provisions of section 33 and the underlying values of the Constitution, bearing in mind that, ... the role of the court is not to second-guess the wisdom of policy choices made by legislators.

1719953 SA 391 (CC) at par 104.

18 Van der Vyver (n 3) 279 submits that a useful guide to establish whether the classification of persons for purposes of the limitation of a fundamental right is reasonably permissible, would be to consider the legality requirements of this section in view of the prescriptions of the non-discrimination clause in $s 9$ of the Constitution. All classifications founded on, inter alia, race, gender, sex, pregnancy, marital status, ethnic or social origin, age, disability, religion, conscience, belief, culture, language and birth are rendered suspect by s 9 . Note that s 33 as it has been referred to in casu has been replaced by s 36 of the Constitution. See too n 93 infra. 
This cautious approach was echoed afterwards in a number of decisions. In $S v$ Manamela $^{19}$ the court explained that it has to engage in a balancing exercise and arrive at a global judgment on proportionality and not adhere mechanically to a sequential checklist. As a general rule, the more serious the impact of the measure on the right, the more persuasive or compelling the justification must be. Ultimately the question is one of degree to be assessed in the concrete legislative and social setting of the measure paying due regard to the means which are realistically available in the country, but without losing sight of the ultimate values to be protected.

The further qualification that limitations of a fundamental right must be justifiable in an open and democratic society clearly envisages a society that differs fundamentally from the one associated with apartheid South Africa. In fact, the true nature of this requirement only comes to the fore when cognisance is taken of the provisions of section $7(1)$, which in essence elevate the democratic values of human dignity, equality and freedom to the status of being the ultimate normative sources of the rights enshrined in the Bill; and of section 39(1) which compels a court to promote the values that underlie an open and democratic society based on human dignity, equality and freedom when interpreting the Bill.

\subsection{The constitutional Grundnorm}

The constitutional Grundnorm of South Africa is a product of the country's past history. The basic norm, which in the case of a discrepancy between

1920003 SA 1 (CC). 20 See too Christian Education South Africa v Minister of Education 20004 SA 757 (CC) par $29-35$.

21 In Coetzee v Government of the Republic of South Africa 19954 SA 631 (CC) the Constitutional Court held that '[w]e need to locate ourselves in the mainstream of international practice' to establish what is meant by this requirement. It is furthermore illuminating to bear the Preamble of the Constitution in mind. Specific reference is made to the motivation for the Constitution qua supreme law of the country to achieve the following:

- Heal the divisions of the past and establish a society based on democratic values, social justice and fundamental human rights;

- $\quad$ Lay the foundations for a democratic and open society in which government is based on the will of the people and every citizen is equally protected by law;

- Improve the quality of life of all citizens and free the potential of each person; and 
different constitutional interests will override any other constitutional provision that comes into conflict with it, is constituted by the equal protection and nondiscrimination provisions in the Constitution. The provision that South Africa is to be an open and democratic society based on human dignity, equality and freedom, makes it clear that in the case of a conflict of constitutional interests, human dignity and equality will be the primary consideration.

The provisions with regard to equal protection and non-discrimination are found in section 9 of the Constitution. Amongst others, it prohibits unfair discrimination on grounds of race, gender, sex, pregnancy, sexual orientation, age, disability, religion, conscience, belief, culture, language and birth. The legislator is also tasked to enact national legislation to prevent or prohibit unfair discrimination. Discrimination on one or more of the grounds set out above will be considered unfair unless it is established that the discrimination is fair.

In this paragraph brief attention will be paid to age as a ground on which discrimination is forbidden. Broadly speaking, it would appear that the legal position reflects a teleological approach - the purpose of differentiating between categories must dictate the ethical propriety of the basis employed to differentiate between them. In other words, the basis of the classification of groups of persons for the purpose of differentiating in law between these categories must be truly relevant with a view to the legal purpose to be served by the classification. Equal protection, therefore, does not mean per se actual equality in the arithmetical sense that would negate all differentiation between categories of people. If the classification is founded on a reasonable basis, and it is truly relevant to the purpose it is meant to serve, classification and differentiation for purposes of law may well fall within a definition of equal

- Build a united and democratic South Africa to take its rightful place as a sovereign state in the family of nations.

22 See S v Makwanyane (supra text accompanying n 19); Van der Vyver (n 3) 283.

23 Van der Vyver (n 3) 289. 
treatment. Of course, practicality and legal certainty must also prevail. Legal certainty dictates that the law operates with fixed age criteria.

\section{4}

In South African law majority is attained at the age of 21. Puberty is reached by girls of 12 and boys of 14 years of age. Boys younger than 18 and girls younger than 15 years of age need ministerial consent to marry. Persons of 16 years are competent to make a will. Below seven years, a child is considered to be doli et culpae incapax and unable to enter into agreements. It is perfectly acceptable that specific age limits are set for the sake of legal certainty, provided of course, that the designated age should not be entirely arbitrary but derive from existing knowledge of human development.

\section{RIGHTS OF EVERYONE WITH SPECIFIC RELEVANCE TO CHILDREN}

\subsection{Introduction}

The Constitution recognises that children are particularly vulnerable to violations of their rights and that they have specific and unique interests.

24 Dicta in the English case of Gillick v West Norfolk Area Health Authority 19853 All ER 402 and provisions of the Convention on the Rights of the Child (1989) deviate to some extent from a rigid interpretation of legal certainty. In Gillick, two passages make it clear that, at least within the parent-child relationship, the development of the child must be taken into account. Lord Fraser of Tullybelton held that parental rights to control a child do not exist for the benefit of the parent, but for that of the child, and that such rights are justified only in so far as they enable the parent to perform his or her duties towards the child and other children in the family. With respect to the evolving capacities of the child, Lord Scarman explained that parental rights must yield to the child's right to make his or her own decisions when the child reaches a sufficient understanding and intelligence to be capable of making up his or her own mind on the matter requiring decision. The principle of law , ... is that parental rights are derived from parental duty and exist only so long as they are needed for the protection of the person and property of the child. The principle has been subjected to certain age limits set by statute for certain purposes; and in some cases the courts have declared an age of discretion at which a child acquires before the age of majority the right to make his own decision. See in this regard too references to Grundrechtsmündigkeit in German literature, inter alia the discussion in Maunz-Dürig-Herzog Grundgesetzkommentar at art 6GG.

25 It is clear that differentiation between the ages of reaching puberty by boys and girls reflects the difference in physiological development between the sexes. As such the legal prescriptions appear to be constitutionally in order. However, if one were to apply puberty for purposes of establishing accountability in private law, it would surely not stand constitutional muster. It is also suggested that the legislator should consider substituting 18 for 21 years as the age of majority in view of the improvement of educational standards, access to secondary education, the exposure of young people to information and to influences that contribute to their early maturity. See Van der Vyver (n 3) 294. 
Provision is made in section 28, therefore, for the protection of specific rights of children. However, they are also entitled as ordinary inhabitants of the country to the protection afforded by the Constitution. Children are entitled not only to the rights contained in section 28, but also to all other rights in the Bill pertaining to them. In this regard the right to equality, the right to education and the right to personal autonomy constructed from the rights to privacy, freedom of religion, freedom of expression and freedom of association read together, are the most important.

\subsection{The right to education}

African children were subjected to inferior education in the pre-1994 public school 27

system. In fact, all school going children of colour fell victim to an unequal and racially defined distribution of resources. ${ }^{28}$ The challenge under the new constitutional dispensation, therefore, is to create an education system that will ensure that the human resources and potential of our society are developed to the full - education does not take place in a vacuum; it is

26 In view of the fact that the provisions of s 9 regarding equality have been dealt with supra, no specific attention will further be paid to this aspect. Reference should, for the sake of interest be made, however, to the unreported decision of the Supreme Court of Appeals in Mthembu v Letsela and Another SCA 71/1998 on 30 May 2000 (unreported) where the extra-marital daughter of a Black man who died intestate challenged the validity of the customary law rule of primogeniture in intestate succession inter alia on the basis that it discriminated unfairly against her on the basis of her sex and gender. The court rejected this argument on the basis that the distinction that excluded her from inheritance was her extra-marital status rather than her sex or gender. Regrettably the court failed to establish whether the rule discriminated unfairly on the basis of extramarital status. See too Bekink \& Brand 'Constitutional Protection of Children' in Davel Introduction to Child Law in South Africa 179.

27 See Maithufi 'Children, Young Persons and School Law' in Robinson The Law of Children and Young Persons in South Africa 238. The inequality inherent in education was born out by the Bantu Education Act 47 of 1953 . Dr Verwoerd, probably the most prominent architect of apartheid, described its purposes as follows: Racial relations cannot improve if the wrong type of education is given to natives. They cannot improve if the result of native education is the creation of frustrated people who, as a result of the education they received, have expectation in life which circumstances in South Africa do not allow to be fulfilled immediately, when it creates people who are trained for professions not open to them, when there are people who have received a form of cultural training which strengthens their desire for the white-collar occupations to such an extent that there are more such people than openings available. See House of Assembly Debates of 17 September 1953 col 3576

28 Van der Vyver (n 3) 266 conveys that in 1982/1983 the per capita expenditure on education was R13850 for Whites, R593 for Coloureds, R871 for Indians and R192 for Africans. In the same fiscal year the teacher/pupil ratio was 1:18 in the case of White 
inextricably intertwined with the socio-economic, cultural and political character of the community it serves.

The Constitution guarantees to everyone the right:

29

- $\quad$ to basic education, including adult basic education, and to further education;

- to receive education in the official language or languages of their choice; ${ }^{30}$ and

31

- $\quad$ to establish and to maintain independent educational institutions.

The wording of section 29 makes it clear that everyone, therefore also children, have an immediately enforceable right to basic education, but that

schools, 1:26 in the case of Coloured schools, 1:23 in the case of Indian schools and 1:42 in the case of schools for African children.

29 S 29(1). This section reads as follows: Everyone has the right

(a) to a basic education, including adult basic education; and

(b) to further education, which the state, through reasonable measures, must make progressively available and accessible.

30 S 29(2) provides that: Everyone has the right to receive education in the official language or languages of their choice in public educational institutions where that education is reasonably practicable. In order to ensure the effective access to, and implementation of, this right, the state must consider all reasonable educational alternatives, including single medium institutions, taking into account - (a) equity;

(b) practicabilty; and

(c) the need to redress the results of the past racially discriminatory laws and practices.

31 S 29(3). This section reads that: Everyone has the right to establish and maintain, at their own expense, independent educational institutions that -

(a) do not discriminate on the basis of race;

(b) are registered with the state; and

(c) maintain standards that are not inferior to standards at comparable public educational institutions. In In re: The School Education Bill of 1995 (Gauteng) 19964 BCLR 536 (CC) the constitutionality of sections of the South African Schools Act 27 of 1966 implicating the future of Afrikaans schools and Christian education was contested. The Constitutional Court upheld their constitutionality.

[i]mense inequality continues to exist in relation to access to education in our country. At present, the imperatives of equalising access to education are strong, and even although these should not go to the extent of overriding constitutionally protected rights in relation to language and culture, they do represent an important element in the equation. The theme of reducing the discrepancies in the life chances of all South Africans runs right through the 
the right to further education is of a rather qualified nature in the sense that the right to such education is couched in the language of progressive implementation. However, in both instances there is a primary duty on the State to provide the support, facilities and services for the realisation of these rights. ${ }^{32}$ The right to receive education in the official language of one's choice in public educational institutions too is of a qualified nature. This right recognises the importance of children receiving education in their mother tongue, but balances this imperative with requirements of practicality by providing that instruction in the official language of choice must only be provided where reasonably practicable. It is furthermore important to note that the right is not to mother tongue instruction, but only a right to instruction in the official language of one's choice.

The right to establish and maintain independent educational institutions, which is also a qualified right, is in the ordinary course of events exercised by parents rather than children. It goes without saying, of course, that children are directly affected by the exercising of this right. In Ex parte Gauteng

\footnotetext{
Constitution, from the forceful opening words of the preamble to the reminder of the past ... Van der Vyver (n 3) 311; Bekink \& Brand (n 26) 179. S 239 of the Constitution provides that a public school is regarded as an organ of state because it exercises public power and performs public functions in terms of the legislation. Being an organ of state, a public school is in a position to violate rights and is therefore bound by the Bill in terms of $s$ 8(1). Public schools, qua organs of state, form part of the broader public education administration and must comply with constitutional prescriptions for regarding administration. Organs of state must be governed by democratic values enshrined in the Constitution, practice open, participative and accountable governance and, amongst others, be development-oriented and promote a high standard of professional ethics.

In the terms of $s 5$ of the South African Schools Act, a public school must admit learners and serve their educational requirements without unfairly discriminating in any way. It is an important function of the school governing body to determine an admission policy of the school but it may not administer any test related to such admission. In addition, no learner may be refused admission to a public school on the grounds that the parent: is unable to pay or has not paid school fees as determined by the governing body; does not subscribe to the mission statement of the school; or has refused to enter into a contract in which he or she waives any claims for damages arising out of the education of the learner. In terms of $s 6$, the school governing body of a public school may determine the language policy of the school but subject to norms and standards which the Minister may determine for public schools in this regard. The section makes it abundantly clear that no form of racial discrimination may be practiced in implementing a language policy. In line with the Constitution which recognises Sign Language as an official language of the country, a recognised Sign Language also has the status of an official language for the purposes of learning at a public school. See
} 
Legislature: In re Gauteng School Education Bill the argument put before the court was that section 32 of the Interim Constitution placed a positive obligation on the State to establish, where practicable, educational institutions based on common culture, language or religion. The Constitutional Court rejected this argument, holding that this section guarantees a freedom - a freedom to establish educational institutions based on a common culture, language or religion. A person can indeed invoke the protection of the court where that freedom is threatened, but the language of the section makes it clear that such educational institutions need not be established by the State.

34

\subsection{Personal autonomy}

Like everyone else, children are entitled to the right to privacy (section 14), the right to freedom of religion, belief and opinion (section 15), the right to

too Bray 'The South African Schools Act 84 of 1996' in Davel Introduction to Child Law in South Africa 285 et seq.

3319963 SA 165 (CC). The decision dealt with section 32(c) of the Interim Constitution which provided that every person shall have the right to establish, where practicable, education institutions based on common culture, language or religion provided, however, that there shall be no discrimination on the ground of race.

34 On 173. The court explains that the object of this subsection is to make clear that while every person has a right to basic education through instruction in the language of his or her choice, those persons who want more than that and wish to have educational institutions based on a special culture, language or religion which is common, has the freedom to set up such institutions based on that commonality, unless it is not practicable. This viewpoint was echoed in Wittmann v Deutsche Schulverein, Pretoria 19984 SA 423 (T) where the mother of a child enrolled at a German school objected to a requirement that the child attend academic religious-instruction classes. In essence her argument ran that this requirement violated her right to freedom of religion. The court held that this subsection guarantees the freedom of individuals to establish their own educational institutions based on their own values. The right to exclusivity on the grounds of culture, language or religion includes the right to exclude non-users of that language and non-adherents of that culture or religion, or to require conformity from them. It follows therefore, that this sub-section recognises the freedom to establish parochial educational institutions with confessional religious observances and instruction. Attendance at religious classes may indeed be made obligatory. The State is not constitutionally obliged to provide funding to these private institutions, but neither is there a constitutional provision to subsidisation. It is clear, therefore, that the right to establish a private school based on a common culture, language or religion must by necessity include the right to exclude those who do not prescribe to the particular culture, language or religion. Freedom of religion as it relates to access to such independent educational institutions amounts to no more than the freedom of 'nonjoinder.' At 454G-455B. See too Bekink \& Brand (n 26) 180. 
freedom of expression (section 16), and the right to freedom of association (section 18).

\section{SPECIFIC CONSTITUTIONAL RIGHTS OF THE CHILD: SECTION 28}

\subsection{Introduction}

With the exception of specific restrictions on their fundamental rights imposed by their youth (e.g. the right to vote is restricted to 'every adult citizen') every child enjoys the same protection in the Bill as his or her adult counterpart. The dictum of the United States Supreme Court in Planned Parenthood $v$ Danforth ${ }^{36}$ that constitutional rights do not mature and come into being magically once one attains the state-defined age of majority, also applies in South African law. ${ }^{37}$ Section 28 does not confer a right to individual self-determination on children. When questions regarding the lifestyle of children, or religion, are addressed, a balance must be struck between their interests, and the interests of their parents and the State. In such instances children must, like everyone else, derive their claims to personal autonomy and self-fulfilment from the right to privacy, and from the rights to freedom of religion, speech and association. The limitation of these rights becomes more difficult to justify as a child grows older, since the responsibilities of parents and the State towards a child are linked to the child's age. ${ }^{38}$ The interest of children in maintaining their own autonomy must therefore be seen in the context of the relationship of dependence that of necessity exists between child and parent. The responsibilities of care and support a parent has towards a child, and the

35 The question whether children have a composite right to individual self-determination to choose their own life style, religion and opinions regardless of the authority of their parents, will be addressed infra.

36428 US 52 (1976) quoted by De Waal et al ( $n$ 1) 456.

37 De Waal et al (n 1) 56 argue that s 9 may prove to be particularly useful for children since it presumes that discrimination based on age is unfair. This would mean that there must be a good reason for not according the same rights, privileges or benefits to children as adults. One such example of arbitrariness may be the fact that in terms of the Choice on Termination of Pregnancy Act 92 of 1996 a minor may decide to terminate a pregnancy, but parental consent is required in terms of s 39(2) of the Child Care Act 74 of 1983 for any other operation.

38 De Waal et al (n 1) 57. Bekink \& Brand (n 26) 180 elaborate to some extent on this explanation by stating that if these rights to, for instance, privacy, freedom of religion or of expression, are limited by parental authority, this limitation can be justified by a parent's duty of care and support toward the child. 
rights and powers a parent can exercise toward a child in order to meet those responsibilities, limit the extent to which a child can lay claim to his or her selfdetermination.

$$
39
$$

\subsection{Personal rights of the child: The right to a name and nationality from birth}

\section{8(1) Every child has the right -}

(a) to a name and nationality from birth;

The right to a name is aimed at the provision and protection of a child's legal identity. Every child's birth must be registered in terms of the Births and Deaths Registrations Act 51 of 1992. If a child's birth is registered his or her name and particulars are entered into the population register. A name entitles a child to have his or her birth so registered. It also enables a child to exercise many of his or her other legally protected rights, e.g. the right to vote once he or she has attained the requisite age to do so. Section 9(6) of this Act conveys that no person's birth shall be registered unless a forename and a surname have been assigned to him. The right to a name, therefore, includes the right to have a person's name registered by the State at birth. ${ }^{40}$ The constitutional right to have a name at birth has important implications for adopted children's searches for their parents' identities. Section 25 of the Child Care Act 74 of 1983 permits an adopted child's surname at birth to be

39 Bekink \& Brand (n 26) 181. Parental authority as such is not protected by the Constitution. Parents do not, therefore, derive a right from the Constitution to veto their daughter's decision to terminate her pregnancy. In terms of s 5(3) of the Choice on the Termination of Pregnancy Act 92 of 1996, a medical practitioner must advise a minor to consult with her parents before performing an abortion. However, the termination of the pregnancy may in terms of the same section not be refused if the child refuses to consult with her parents.

40 Bekink \& Brand (n 26) 181. In the South African context, this right is of a rather unique nature as is illustrated by the following example: On 18 July 1918 a boy was born in Umtata and given the name Rohlihlahla (meaning 'pulling the branches of a tree' or 'troublemaker'). When the boy whose last name was Mandela, reached the age of seven, he was sent to a school of the Wesleyan Church. On the first day of school his teacher informed him that he would henceforth answer to the name of Nelson. It was not uncommon for Africans to be given, or to assume, a Western pseudonym that would facilitate communication with non-African instructors or employers. Against this background, it may well be that the right of an African child to be known under his or her real name inspired this clause in the Constitution. 
changed to that of the adoptive parent or parents. This provision may be seen to violate the right of the child to a name from birth. However, it does seem to be reasonable and justifiable in an open and democratic society based on human dignity, equality and 41

freedom.

This section also affords every child the right to a nationality from birth. The aim of this section is clearly to guard against statelessness with regard to children, rather than to operate as a direct means of acquiring South African citizenship. ${ }^{42}$ In this sense one can say that the right to nationality is intended to protect a child's international legal identity and particularly to protect a child against the loss of South African nationality.

41 Unless special provision is made under national legislation for accessing the birth records of adoptees, s 25 can operate to undermine the right of adoptees to know their legal identity at birth. The denial of a child information about his or her parents may lead to genealogical bewilderment. See De Waal et al (n 1) 458; Van der Vyver (n 3) 304; Bekink \& Brand (n 26) 181.

42 Keightly 'Nationality' in Boberg's Law of Persons and the Family 83. Keightly argues that this is evidenced, first, by the fact that the right attaches to all children and not only to those who are South African citizens and, secondly, by the fact that what is guaranteed is a right to a nationality and not to South African nationality. In the third place, she argues that this section refers to the right to nationality rather than to citizenship. This indicates that the section is concerned with a broad, external relationship between a child and a state, rather than with the narrower, internal relationship implying domestic legal rights and obligations. The section is therefore aimed at ensuring that every child in South Africa has a claim to fall under the protection of a state, even if the state is not South Africa. Of course, if a child is entitled to South African citizenship, the concept of citizenship and nationality would converge and the child's right to nationality would be satisfied by the state's recognition of his or her citizenship. While this subsection does not directly guarantee South African nationality for children within South Africa's borders, it may have the effect of placing obligations on the State to grant South African citizenship to certain children, particularly those who are, or are potentially, stateless.

43 Bekink \& Brand (n 26) 182. The authors convey that nationality as a legal status enables a person to exercise the international dimension of citizenship. As such, it denotes a person's right to a passport of the country of his or her nationality and also the right to protection by the state of nationality if he or she is injured in another country. While this right is widely recognised in international law, it has particular historical significance in South Africa. During the apartheid years many South Africans lost their South African nationality when they became nationals of the so-called homelands. This meant, amongst other things, that they could no longer move about freely in South Africa, were not entitled to South African passports and were not entitled to South African diplomatic protection abroad. See too Van der Vyver (n 3) 304; De Waal et al (n 1) 459; Keightly (n 42) 84. Van der Vyver 305 sounds a serious warning, though. In the United States all persons born within the country, including those of alien parents and even of illegal immigrants, are entitled to United States citizenship. It is not sure what is meant by 'every child' and 'nationality from birth' in this provision. American generosity in regard to citizenship by birth stemmed from a misinterpretation of Calvin's Case, decided in England in the 17th century, and there is no reason 


\subsection{Family rights of the child}

28(1) Every child has the right -

(b) to family care or parental care, or to appropriate alternative care when removed from the family environment;

\section{Background}

It is submitted that the right of the child to family or parental care can only be appreciated if cognizance is taken of the specific socio-economic background underlying the need for the protection of these rights in the Constitution. The policy of apartheid which formally regulated racial affairs, had a particularly devastating impact especially on Black families and the children of such families. The constitutional measures were meant to remedy a wrong so negatively experienced by a substantial portion of the population that specific protection of these rights of children were considered appropriate. The question that needs to be answered, though, is whether the constitutional measures are sufficient to remedy the wrongs done in the name of apartheid.

During the apartheid era, the right to own, occupy, or use land, by and large depended on a person's racial credentials. ${ }^{44}$ The Group Areas Act 36 of 1966 bore out on this, aiming as it was, at dividing the whole country into separate areas each destined for exclusive occupation by members of a particular racial group. When such a group area was proclaimed for occupation, members of other groups became 'disqualified persons' in terms of the Act and occupation of the land or premises in question was illegal if nonmembers did not hold a permit. An offence was also committed by a person who allowed a disqualified person to occupy. Members of a specific group who were lawfully in occupation before the area was proclaimed, had a moratorium of at least one year before their presence became proscribed. Thereafter, any contract from which a disqualified person derived his or her right of occupation

whatsoever why the same generosity should be applied when interpreting s 28(1)(a) of the South African Constitution. See Robinson 'An overview of the provisions of the South African Bill of Rights with specific impact on its impact on families and children affected by the policy of apartheid' in 1995 Obiter 99 et seq and the sources referred to there. 
(e.g. a lease) lapsed automatically and the person concerned could be ejected from the land or premises by an order of a local magistrate.

In terms of the provisions of this Act (and also others not specifically mentioned) all Blacks who became citizens of the so-called TBVC-countries (Transkei, Bophuthatswana, Venda and Ciskei) legally were foreigners in South Africa, the intention being that they were to exercise their political rights in their homelands. However, these provisions were only part of the picture and had to be viewed in conjunction with other legal measures aimed at securing the benefits of cheap labour for 'white South Africa' which was available by the abundance of unskilled and semi-skilled labour. A system of influx control was consequently set up

[t]o balance two apparently contradictory white needs -an exclusionary need to obtain political security by controlling and policing the number of Africans in white areas, and an inclusionary need to ensure a supply of cheap labour within these areas.

The major industrial and commercial areas of South Africa were all in 'white areas'. To ensure an adequate and cheap labour supply in these areas, but simultaneously keeping African families in the rural areas, a battery of controls and regulations was created. African labour was to enter cities only on a temporary basis and influx controls were set up to admit only those who were able bodied, willing to work on short term contracts and usually who were male.

Section 10(1) of the Black (Urban Areas) Consolidation Act 25 of 1945 was the legal instrument by means of which the influx of Blacks into the industrial and commercial areas was regulated. Urban residential rights were granted in terms of section 10 and the qualifications required for such rights were high. Section 10(1)(a) rights were available only to those who were born in a town and had lived continuously in that town for a period of 15 years since they were born. Those who had worked continuously in registered employment in 
one town for 10 full years for one employer or had lawfully and continuously lived in one town for 15 years, qualified for section 10(1)(b) rights. The wives, daughters and unmarried sons under the age of 18 years of those with section 10(1)(a) rights, and, to a limited extent, those with section 10(1)(b) rights, had a legal right in terms of section $10(1)(c)$ to remain with them once they had taken up residence with them in town.

Besides Black people residing in 'white' areas in terms of section 10, Blacks could enter the areas by means of a migrant labour system, which was established to provide labour within these areas. The premise of the migrant labour system was that a large number of Blacks would reside in 'white' areas only when their labour was required, but would be resident in the homelands at all other times. No contract could be for a period in excess of one year, after which the worker had to return to the homeland.

Administrative policies also played a major part in the process of exclusion. The Government's housing policy for example served as an instrument of influx control. In 1958 it was decided by Government that no funds would further be made available to local authorities to subsidise the provision of sub-economic housing for Blacks. Because local authorities were now required to finance the building of such housing out of their own funds, new housing stock was not even sufficient to cater for the natural increase of the Black population in the cities, let alone the population growth arising out of the process of urbanisation. In 1968 comprehensive regulations were introduced to control the occupation of housing in Black residential areas. The regulations strictly limited the categories of people for whom family homing could be provided and made it a criminal offence to live in a Black residential area without a specific permit issued by the township superintendent.

Despite criticism, Government always maintained that the influx control measures were merely to safeguard urban Black families from competition from rural immigrants. The view was substantiated to a degree by a policy in terms of which employers were not permitted to requisition for rural labour if there were urban Black people available to do the work. In practice, though, the effect of the system of influx control on urban African family life was devastating. The family was protected by law only when both parties had section 10 rights. In cases where one or both parties were in town illegally, influx control could prevent recourse to the law to regularise their de facto family. The way in 
which this occurred, was as follows: Where a couple wished to marry, but the man did not have section 10 rights, the woman could legally loose hers if they married. Consequently many women preferred staying unmarried rather than losing their residence rights. Due to attitudes generated by customary law, such women did not decline to have children, since producing children for a man is generally considered to retain him, whether in or out of marriage. Male objections to birth control were widespread. To these considerations were added the impact of urbanisation, backed by only minimal social security, which ensured that children, in or out of wedlock, remained desirable. 
In the event where the man, but not the woman, had section 10 rights, she could only join him after marriage if she had section 10(1)(a) rights and approved accommodation in the form of his house; permission to occupy accommodation in someone else's house was not sufficient. This requirement effectively prevented most wives and children of section $10(1)(b)$ men of joining them. Consequently, while men could well marry rural women despite this requirement, the prevention of their families from joining them meant that such men frequently had second, irregular, families with women already qualified to live in town.

The impact of these measures on family life among Black families hardly need elaborated upon. It was impossible for a migrant worker to bring his family legally to town to live with him. As the administration of influx control became more efficient and penalties for illegal residence became more severe, it was increasingly becoming difficult to reside illegally. Self-built homes and shelters were demolished in systematic fashion. The increasing number of landless people in the so-called bantustans caused by the forced removal of people from 'white areas' and their dumping in closer settlements, markedly led to a deterioration in family structures. If the family had access to land previously, and therefore to subsistence, the permanent family unit usually consisted of the children, women of all ages and old men, the able-bodied men working elsewhere. Although these units did not have the qualities of a normal family group, it nevertheless provided some sort of a stable nuclear unit with recognised structures. However, where there was no land, many family units only consisted of a grandmother and a large number of children abandoned her care. These children often grew up, literally learning nothing at all. 
In urban areas the destruction of family life had different roots, but the consequences were equally disastrous. As indicated above, it was made very difficult for the families of people qualifying in terms of section 10 to join him or her in the 'white' area. Government's manipulation of housing which had been designed to control the presence of Black people in urban areas, led to waiting lists in all areas to grow to unmanageable proportions. The gross overcrowding which had resulted, distorted the whole pattern of family life in the Black community. Houses built for nuclear family units were bursting at the seams with three or four generations vying with one another for space. Privacy rarely existed and the consequent distortions in family relationships lead to brother turning against brother in their attempts to obtain the tenancy of the family home upon the death of the parents.

Presently the phenomenon of street children (and the concomitant crime rate) is a major problem in South Africa. Poverty and poor welfare conditions surely are at the root of the problem and when one considers the general state of family life as set out above, it comes as no surprise to learn that the rate of births adding to the over $60 \%$ illegitimacy rate is rapidly increasing. It is commonly accepted that the ever increasing number of street children is directly linked to the lack of housing. In fact, it was ironical that the homes that were demolished often were those of families who in one way or another struggled to maintain a family life. Once the shelter was demolished, the family was almost always divided, because there was nowhere else to stay together. The state of affairs lead an author to conclude that 
[m]any, many others have lost all understanding of family organisation and gave up the struggle long ago. It merely created new anxieties. ... There are dozens of other aspects of the destruction of family life directly caused by the apartheid system. ... we have a national disaster on our hands.

The Constitution does not protect the family qua institution. To my mind this should have been the focal point of section 28(1)(b). The urge for the rebuilding of the family structure has already in 1983 been voiced as "probably the most fundamental problem that will face any democratic government coming to power in the future." It is submitted that the provisions of section $28(1)(b)$ fail to meet this challenge and to remedy the wrongs done to families in the name of apartheid. In fact, not only should the protection of the family as an institution have been provided for, but concomitantly, the right of parents to care for, and educate their children. At the same time the duty of the State to watch over a parent's exercising of his or her rights should also have been stipulated for. 48

46 Duncan 'On the Family' 1983 Work in Progress 38.

47 Constitutional Principle II of Schedule 4 of the Interim Constitution (n 1 supra) required the Constitution to include universally accepted fundamental rights. The Bill of Rights does not contain explicit protection of the right to marry and to raise a family. In the First Certification Judgement (n 1) the court held that no single universal right to family life and marriage could be identified. Furthermore, the court held that diverse societies tend not to include such a right in their constitutions for the fear of constitutionalising one particular family form to the exclusion of others. By refraining from entrenching a right to family life, the framers of a constitution mean to avoid difficult arguments about protection of the nuclear or the extended family. According to the court the Constitutional Assembly took the option of tolerance for diversity. A trinity of values (human dignity, freedom and equality) will play an important role in the protection of marriage and family life. These values would prohibit arbitrary State interference in the right to marry or to establish and raise a family. It can be concluded therefore that this exposition of the court destines dignity for the constitutional protection of the family. In par 100 the court explains that there can be no doubt that the Bill of Rights prohibits the kinds of violations of family life produced by the apartheid system and the institutionalised migrant labour system. Without entering into debate on the issue, one can conclude that the court interprets the obligations of the State primarily as a negative one - the State is not to interfere in family life. Regrettably, though, no mention is made of protection for the family as an institution or of a positive obligation on the State to occupy itself with the rebuilding of families e.g. by implementing policies aimed at such upliftment.

48 For a comprehensive discussion of the contents of this paragraph, see Burman 'The interaction of legislation relating to urban Africans and the laws regulating family relationships' 1985 Urban Black Law 89; Duncan (n 46) 38; Chaskalson 'The right of Black persons to seek employment and be employed in the Republic of South Africa' 


\title{
Nature of the right
}

\author{
The right to family care or parental care requires the family ${ }^{49}$ or parents of a child, or the \\ 50 \\ State, to provide care to that child. By using the word 'care', the Constitution radically \\ deviates from the notion of parental 'authority' of the common law. ${ }^{51}$ There can be little \\ doubt that the authority of the pater has lost
}

1985 Urban Black Law 33; Patel Children and Women in South Africa: A Situation Analysis 1993. (Report for UNICEF); Corder 'The right and conditions of entry into and residence in urban areas by Africans' 1985 Urban Black Law 45; Budlender (n 45) 159.

49 In Heystek v Heystek 20022 SA 754 (T) the court interpreted s 28(1)(b) to read that parental care is not confined to natural parents but that it also extends to stepparents, foster parents and adoptive parents.

50 It is important to note that the duty imposed in this case is a positive one. This means that the duties implicated by this section are of the few imaginable instances where a positive constitutional duty will apply horizontally. See Bekink \& Brand (n 26) 183. The provision that the child has a right to family care, includes the right to be cared for by the extended family. See Robinson "The Child's Right to parental and Family Care: Some Brief Remarks' in 1998 Obiter 329 et seq. This deduction can be made from the provisions of s 15(3) of the Constitution which reads as follows:

(a) This section does not prevent legislation recognising -

(i) marriages concluded under any tradition, or system of religious, personal, or family law; or

(ii) systems of personal and family law under any tradition or adhered to by persons professing a particular religion. The tribal system that prevails among indigenous people in South Africa is well known. The emphasis in these social structures falls on the extended family as a means by which society is organised and one's status is determined within the framework of his or her family. There can be no doubt that the true meaning of the words 'any tradition' in s 15(3)(ii) of the Constitution was to convey that the child's right to family care extended also to the extended family. It would appear that the family is to be regarded as the primary institution within which the child must grow up. By placing the right to family care before the right to parental care, and by linking the concepts of family and parental care with the word 'or', the conclusion may be drawn that the Constitution attaches more weight to family care than to parental care when it comes to the care of children. The concept of parental care, which is typically reflected in terms of exclusivity in the sense that it relates to the nuclear family, must be elaborated upon by a definition of family that lacks such exclusivity. See e.g. Bethell $v$ Bland 19962 SA 194 (W)

51 The material elements of the duty implied by this right, in essence are contained in s 28(1)(c) and (d) of the Constitution. These subsections provide for the child's right to basic nutrition, shelter, health care and social services as well as the right against maltreatment, neglect, abuse and degradation. These rights will be addressed infra. As indicated in the text accompanying $n 9$ supra, these instances should be seen as some of the few examples where horizontal application of the Constitution is implicated. In a most interesting decision in Jooste v Botha 20002 SA 199 (T) the court held that whereas it is clear that children have a legitimate interest in general physical, intellectual and emotional care within the confines of the capabilities of their care givers, it is significant that the Constitution does not state that parents are obliged to love and cherish their children or to give them attention and interest. What $s$ 28(1)(b) envisages, in fact, is a child in care of somebody who has custody over him or her. To that situation every child is entitled and the State is constitutionally obliged to establish, safeguard and foster such a situation. The State may not interfere with the integrity of the family. Therefore, the court concludes, s 28(1)(b) sets out vertical socio-economic rights against the State. See too text accompanying $\mathrm{n} 54$ infra. In Patel v Minister of 
much of its harshness in modern South African law, as the best interest of the child invariably serves as a qualification to the exercise of parental power. However, its origin as an institution favouring the interest of the parents, rather than those of the child, remains. By stating that a child has a right to family or parental 'care', a definite nuance is placed on the parent-child relationship. The use of the concept care, denotes an acknowledgement that children are vulnerable and lack maturity of judgment and experience. This concept consequently has a radically different basis, namely that the parent-child relationship is to be defined in terms of the care that is owed to the child to assist him or her to overcome his or her own vulnerability and lack of maturity relating to judgement and experience.

The material elements of the duty implied by this subsection are largely provided for in sections 28(1)(c) and (d). However, the aspect of love is not covered by these sections that, in essence, relate to the right of the child to basic nutrition, health services, shelter and social services and the right against maltreatment and neglect. ${ }^{53}$ The question whether a parent is constitutionally obliged to provide for his or her child's intangible needs was

Home Affairs 20003 All SA 256 (D) an illegal immigrant who was married to a South African national, was arrested and detained by virtue of a detention and removal warrant. In an urgent application to order the Minister to have him released from custody, it was contended, inter alia, that the particular statutory enactment was unconstitutional and in breach of the constitutional rights of the immigrant and his children to live together as a family. The court took into consideration that the respondents have not taken into account or weighed in the balance the right of the immigrant's children to family or parental care. See too Heystek v Heystek (n 49 supra). In this case the court held that the constitutional notion of parental care and the paramountcy of the best interests of the child require an attitudinal shift from an antiquated Germanic parent and child relationship, which formed the substratum of the common law, to the rights of the child, which includes parental care and family care. See too Allsop v McCann 20012 SA 706 (C); Swarts v Swarts 20023 All SA 35 (T).

52 Robinson ( $n$ 50) 333. It is not foreseen that the use of 'care' in the Constitution will lead to major changes in South African law. The High Court as upper guardian of all children in its jurisdiction, has in any case always seen its function to protect and advance the best interest of children. Nuances that may be expected to result because of the emphasis on the child's right to care, may, in conjunction with the right of the child that his or her best interests shall be of paramount importance, relate to the permission required by the child to marry. In terms of the Marriage Act, 25 of 1961 a court may interfere in the refusal of the parents to the marriage of their child on the grounds that the refusal was without sufficient reason and that the consent to such marriage would be in the best interests of the child. It is submitted that in view of the fact that care only aims at serving the interests of the child, this provision will have to be reconsidered.

53 See text accompanying $n 87$ infra. 
dealt with in the case of Jooste $v$ Botha. ${ }^{54}$ In this case the plaintiff was an 11 year-old boy born from an extra-marital relationship. He based his claim for delictual damages for, amongst others, emotional distress and loss of amenities of life, on the constitutional ground that he had a right to parental care. These damages were caused by his natural father's refusal and failure

... to admit that he is his natural son; to communicate with him; to render him love, cherishment or recognition; to show any interest in him; and to take any steps that would naturally be expected of a father towards his son.

Taking as its point of departure the unenforceability of conjugal rights by order of court, the court states that not only in its relationship between man and woman is marriage unique, but so are also the multiple relationships that flow from such union. It is true that a bond of kinship evolves which society expects of parents and children to honour. But it does not grant rights to, and impose concomitant obligations, upon the parties except in the economic sphere. Where there exists no legal obligation on parents to love their legitimate offspring, it is axiomatic that there can be none in respect of extra-marital children. ${ }^{55}$ It can be concluded, therefore, that the bond of love is not a legal bond and neither the common law nor statutory law recognises the right of a child to be loved, cherished, comforted or attended to by a non-custodian parent as creating a legal obligation. The court also advances another reason, namely lex non cogit ad impossibilium - the law will not enforce the impossible. Law cannot create love and affection where there are none. Relying on the rule ubi remedium ubi ius, (there is only a right where there is a remedy) the court held that it would be rather senseless to interpret the right of the child to parental care so as to impose an obligation to love the child if such an obligation would not be possible to enforce legally.

The wording of section 28(1)(b) relating to parental or family care, initially caused uncertainty with regard to the question who is to be considered the 
primary caregivers of the child. The right to parental or family care is a typical social right that is enforceable against the State. As a so-called second-generation right, it places the State under an obligation to act positively towards the fulfilment of the particular right. The question that arose, was whether this right could be treated on the same basis as the right, for instance, to adequate housing. ${ }^{57}$ This issue has now finally been solved. The Constitutional Court held in Government of the RSA $v$ Grootboom that the constitutional obligation to provide shelter to children is imposed primarily on the parents or family and only alternatively on the State. The obligation of the State, therefore, is to provide shelter to those children who are removed from their families. The Constitution does not create any primary State obligation to provide shelter on demand to parents and their children if children are being cared for by their parents or families.

The right of the child to appropriate alternative care when removed from the family environment clearly operates against the State. This provision inhibits legislation or administrative action which has the effect of separating children from their parents. The primary duty to provide care to a child rests on his or her parents and family. Apart from the duty incumbent on the State to provide alternative care when family or parental care is lacking, the right of the child in terms of this subsection imposes an obligation on the State to respect existing family or parental care and to limit its interference in such existing care to cases where it is justified.

57 It is self evident that if one were to argue that the right of children to family care or parental care qua second generation right is unambiguous in its wording and that the State is directly responsible to provide family or parental care, the implication would be that the common law rights of parents, and custody law rights of families as instances of first responsibility towards the child, would be disregarded. This could never have been the intention behind this subsection as it would imply that parents and families would be delegates of the State in the caring and upbringing of their children. As such it could also bring the result about that the best interest of the child would be the determining factor in the parent-child relationship or family-child relationship. Such a consequence is simply not tenable as parents and families are under a constant duty under a variety of circumstances to consider what would be the best for the child. Except for the fact that from a legal theoretical point of view it would be wrong to burden parents and families with this criterion, it would also not be practical to apply it in the day-to-day life of children. See Robinson (n 50) supra 336.

5820011 SA 46 (CC) par 77. See further discussion of the Grootboom case in $n 88$ infra.

59 Bekink \& Brand (n 26) 185; De Waal et al (n 1) 460. 
The right to alternative care includes the right to adoptive or foster care and the right to be cared for by the State when the child is in need of care. The Child Care Act ${ }^{60}$ contains comprehensive provisions regulating such alternative care. Bekink and Brand warn, however, that the manner in which a decision to remove a child from the care of his or her family and placed in the care of the State is taken and implemented, is open to criticism. This is so largely because such decisions in general terms do not provide sufficiently for the participation of the child or parents in the decision to take the child into care, and also that they do not provide sufficiently for measures through which the cohesion of the family may be maintained while the child is in State care.

61

\section{Specific instances relating to children's rights and parental care within constitutional prescriptions}

\section{(i) Children's rights with regard to custody upon divorce of their parents}

The best interests of the child are the paramount consideration regarding custody qua incident relating to the day-to-day care and control of such child's person. Once the particular needs of a child have been ascertained, the parents are assessed in order to establish which parent would be the more suitable custodian, having regard to the individual personalities and qualities of the parents and also their respective circumstances. What is in the best interests of the child is a question of fact that has to be established ad hoc in each individual case. It is an objective assessment within the framework of the specific circumstances that pertain to each case. ${ }^{62}$ The interests of the child

6074 of 1983.

61 Reference is made by the authors to, inter alia, the fact that legal representation for children in such proceedings is not compulsory and there is no appeal against a decision of the children's court. Furthermore, rehabilitation of the child's family while the child is in care is not pursued vigorously enough and children are often placed in care facilities unreasonably far from their homes, causing their parents not being able to visit them. See Bekink \& Brand (n 28) 185; De Waal et al (n 1) 462; Van der Vyver (n 3) 306.

62 Palmer 'The best interests criterion: An overview of its application in in custody decisions relating to divorce' in Keightly Children's Rights 102 warns that the concept of best interests of the child may be indeterminate. She explains it thus: [i]t has thus become settled law in South Africa that where a custody decision is to be made by the Court, that decision is to be made in the light of the best interest of the children concerned: i.e. an objective assessment within the particular framework of the specific circumstances that pertain to each case. The fact that the concept of best interests of the child is indeterminate is seen by many to be desirable. In this

way the ever-changing social values and standards and customs may be reflected in 
refer to the welfare of the child and welfare must be taken in its widest sense to include the economic, social, moral and religious considerations. ${ }^{63}$ Emotional needs and ties of affection must also be considered and in the case of older children, their wishes should not be ignored.

64

decisions about the custody of children. Applying the concept is always difficult, because what is best for a specific child, or children in general, can be determined only if all the options are known, which, of course, is impossible. Not only ... but the ability to predict the future is beyond the best of us. Knowing which factors to take into account when deciding what is in the child's best interests, is also difficult. Is the child's security and happiness paramount? Is his religious and moral welfare paramount? Is his or her material welfare the most important consideration? How much weight, if any, should be given to the child's own wishes? These questions cannot be answered determinedly because the circumstances of each child and his or her family situation differ from that of another. Generally it is thought that a combination of these factors will best find out what is in the child's best interests.

63 In McCall v McCall 19943 SA 201 (C) the court formulated a comprehensive list of criteria which courts can use as a standard on the facts of a specific case to determine what custody arrangements will best serve the interests of the child concerned:

(a) the love, affection and other emotional ties which exist between parent and child, and the parent's compatibility with the child; (b) the capabilities, character and temperament of a parent, and the impact thereof on the child's needs and desires; (c) the ability of the parent to communicate with the child and the parent's insight into, understanding of and sensitivity to the child's feelings; (d) the capacity and disposition of the parent to give the child the guidance which he or she requires; (e) the ability of the parent to provide for the basic physical needs of the child, the so-called creature comforts, such as food, clothing, housing and the other material needs -generally speaking, the provision of economic security; ( $f$ ) the ability of the parent to provide for the educational well-being and security of the child, both religious and secular; ( $g$ ) the ability of the parent to provide for the child's emotional, psychological, cultural and environmental development; (h) the mental and physical health and moral fitness of the parent; (i) the stability or otherwise of the child's existing environment, having regard to the desirability of maintaining the status quo; (j) the desirability or otherwise of keeping siblings together; $(k)$ the child's preference, if the court is satisfied that in the particular circumstances the child's preference should be taken into consideration; (I) the desirability or otherwise of applying the doctrine of same sex matching; and $(\mathrm{m})$ any other factor which is relevant to the particular case before the court.

64 See Dijl v Dijl 19664 SA 260 (R); French v French 19714 SA 298 (W). In French the court set out in order of importance four categories of considerations to determine a child's best interests. The primary test is how the sense of security of the child will be preserved. Secondly, the suitability of the custodian parent is to be tested by enquiring into his or her character, into the religion and language in which the children are to be brought up, and also into the fitness of the proposed custodian to guide the moral, cultural and religious development of the child. Thirdly, material considerations relating to the child's well-being, and finally, the wishes of the child will be considered. 


\section{Gay/lesbian parents}

As set out above, section 9 of the Constitution prohibits unfair discrimination either directly or indirectly inter alia on the grounds of sexual orientation. In the case of Van 65 Rooyen $v$ Van Rooyen, a decision handed down immediately before the Interim Constitution came into operation, the best interests of children in an application for an order defining the applicant's rights of access to her minor children were considered in view of the fact that she had been participating in a lesbian relationship. The court came to the conclusion that any right thinking person would say that it is important that children stay away from confusing signals as to how sexuality of the male and female should develop. ${ }^{66}$ Such signals are given by the fact that the children know that, contrary to what they should be taught as normal or what they should be guided to as to be correct (that is, a male and a female sharing a bed), two females are doing this as a matter of preference and of mutual emotional attachment. The court explains that this signal is detrimental to the child because it is the wrong signal.

Van Rooyen has been emphatically rejected after the new constitutional dispensation came into force. In Ex Parte Critchfield ${ }^{67}$ the court concluded that

[i]n a society such as ours which proscribes discrimination on the basis of sexual orientation, these encounters can be viewed in no more serious a light than conventional adultery. ... in my view, the Court should not be particularly concerned with the sexual predilections of litigants when it comes to custody matters. It encourages a voyeurism in public life that demeans us all. It is an entirely different matter where

6519942 SA $325(\mathrm{~W})$.

66 Prior to the Interim Constitution a court would determine the public policy by relying upon previous precedents, and also by a priori deductions from broad general principles. As was the case with the English courts, it was not practice for litigants to lead sociological or economic evidence as to whether particular practices were harmful. See Olsen v Standaloft 19832 SA 668 (ZSC). It is now clear that the constitutional ethos projected by the equality clause in the Constitution serves as the norm in terms of which private-law norms and principles have to be interpreted. See text accompanying $n 16$ supra.

6719993 SA 132 (W). 
such predilections pose an actual or potential threat to the welfare, psychological or physical, of young children.

In $V v V^{68}$ it was found that the court in Van Rooyen had made a moral judgment about what was normal and correct with regard to sexuality and about homosexuality which it found to be abnormal per se. Referring to the limitations allowed by the Constitution on fundamental rights, the court explains that there may well be situations where a court will override the equality clause in the best interests of the child, but it would then consider the reasonableness of such limitations. The court concludes, therefore, that a discriminatory order by a court against a lesbian mother for access rights to her children that is based solely on her sexual orientation will not easily pass constitutional muster. In the same way a court cannot take cognizance of racism or religious intolerance when it decides on the access of the mother to her children, it cannot take cognizance of prejudice in our society. To do that would be to unreasonably limit, or perhaps even negate, the essential content of the right not to be discriminated against on the ground of sexual orientation.

6819984 SA 169 (C).

69 The development of jurisprudence with regard to the adoption of children by gay or lesbian couples has proceeded along similar lines. S 17 of the Child Care Act 74 of 1983 lists the categories of people entitled to adopt children. It specifically allows for the joint adoption of children by married couples and by "a married person whose spouse is the parent of the child". It makes no provision for the joint adoption of children by partners in a same-sex relationship - if people involved in such a relationship want to adopt a child, it would only be possible if one such partner would adopt a child in his or her own right. Even though he or she may intend to raise the child with his or her partner, the partner will have no legally recognised rights in relation to the children. (In essence, the same argument relates to the provisions of the Guardianship Act 192 of 1993 - parents of a child born in wedlock have joint guardianship of the child.) This position is in contradistinction to married persons who may jointly adopt a child. They are then joint guardians of that child. In Du Toit $v$ Minister Welfare and Population Development 20032 SA 198 (CC) it was argued before the court that these provisions violated the rights of the applicants by unfairly discriminating against gay and lesbian parents on the grounds of sexual orientation and marital status. It was also contended that the absolute prohibition of joint adoptions by same-sex parents was not in the best interests of adoptive children who are placed in the families of adoptive parents involved in permanent same-sex life partnerships. Furthermore the argument was that the "non-parent' partner in the relationship was denied due recognition and status as parent of the children. (In casu, both partners had applied in 1995 to adopt the children, but due to relevant statutory provisions, custody and guardianship was awarded to one only.) The court held that the institutions of marriage and family are important social pillars that provide for security, support and companionship between members of our society and that these institutions play a pivotal role in the rearing of children. However, the court indicates that these issues must be approached on the basis that family life as contemplated by the Constitution can be provided in different ways and that legal conceptions of the family and what constitutes family life could change as social practices and traditions change. In addition, the paramountcy of the best interests of children must at all times be the guiding principle. Against this background, the court argues that the statutory provisions exclude from their ambit potential joint adoptive parents who are unmarried, but who are partners in permanent same-sex relationships and who would otherwise meet the criteria set out in the Child Care Act. The exclusion of such people defeats the very essence and social purpose of adoption, which is to provide the stability, commitment, affection and support important to a child's development that can be offered by suitably qualified persons. Therefore, excluding partners in same-sex life partnerships from adopting children jointly where they would otherwise be suitable to do so, would be in conflict with the principle regarding the best interests of the child. The relevant provisions of the Child Care Act therefore deprive children of the possibility of a loving and stable family life as required by $s$ $28(1)(b)$. The court adds that this is a matter of particular concern given the social reality of the vast number of 
parentless children in South Africa. On this basis it is clear that the provisions are in conflict with s 28(2) which provides for the best interests of the child to be of paramount importance. Of importance too, is the acceptance by the court that the non-recognition of the "non-parent" partner, in the context of her relationship with her partner and of their relationship with the siblings, perpetuated the fiction of family homogeneity based on the one mother/one father model. The court found on the evidence presented that the applicants constituted a stable, loving and happy family and that the failure by law to recognise the value and worth of the "non-parent" partner as a parent to the siblings was demeaning. As such, the failure limited her right to dignity. It must be emphasized, however, that the court strongly conveyed that in each decision concerning adoption, prospective adoptive parents should be evaluated on a case-by-case basis to ensure that only suitable couples will be entitled to adopt children jointly. In the resent judgement of $J \& B$ v Director General: Department of Home Affairs (unreported as yet; Case No CCT 46/02 decided on 28 March 2003) a most interesting set of facts presented itself. The applicants in the case have been partners in a same-sex life partnership since 1995. In August 2001 second applicant gave birth to twins. They were conceived by artificial insemination. The male sperm was obtained from an anonymous donor. The female ova were obtained from the first applicant. The applicants applied to be registered and recognised as the parents of the twins. There was, of course, no legal impediment with regard to the second applicant, as the "birth mother" of the children. However, the appropriate regulations to the Births and Deaths Registration Act 51 of 1992 only make provision for the registration of one male and one female parent. In addition, the applicants sought to have s 5 of the Status of Children Act 82 of 1987 declared constitutionally invalid on the grounds that it was inconsistent with the rights entrenched in the Bill. This section reads as follows:

(1) (a) whenever the gamete or gametes of any person other than a married woman or her husband have been used with the consent of both that woman and her husband for the artificial insemination of that woman, any child born of that woman as a result of such artificial insemination shall for all purposes be deemed to be the legitimate child of that woman and her husband as if the gamete or gametes of that woman or her husband were used for such artificial insemination.

(b) for the purposes of paragraph (a) it will be presumed, until the contrary is proved,

that both the married woman and her husband have granted the relevant consent. The High Court struck out the words 'married' where it appeared in the subsections and read in the words 'or same-sex life partner' after the word 'husband'. However, even though the Supreme Court of Appeal, a High Court or court of similar status may in terms of $s 172$ of the Constitution make an order concerning the constitutional invalidity of an Act of Parliament, such an order has no force unless it is confirmed by the Constitutional Court. Hence the application to the Constitutional Court. The Constitutional Court found that in as much the provisions of $s$ do not permit the first applicant to become a legitimate parent of the children, they unfairly discriminate between married persons and applicants as permanent same-sex life partners. As such these provisions are inconsistent with the equality clause in s 9 . The court emphasises that comprehensive legislation regularising relationships between gay and lesbian persons is necessary. It is unsatisfactory for the courts to grant piecemeal relief to members of the gay 
The Constitution does allow for fundamental rights to be limited by law of general application where the limitation is reasonable and justifiable in an open and democratic society based on freedom and equality, and where it does not negate the essential content of the right. While it is clear that currently existing bigotry and its consequences does not in itself create a valid reason to limit the constitutionally guaranteed rights of a gay or lesbian parent, it is equally clear that while the child is growing up there may be strong recrimination from peers and other parents against such child when it becomes known that his or her parent is gay or lesbian. The child may also become confused by the parent's unwillingness to conform to a generally accepted norm. There is in terms of the equality clause indeed nothing abnormal or wrong about a homosexual relationship, but it may be in the best interests of a child to discriminate against its homosexual parent if that would be the only way in which the child would be spared unnecessary suffering.

\section{Maternal preference}

South African courts have in the past expressly favoured mothers when it came to the custody of their minor children. This was especially true of young children. ${ }^{70}$ It was only if the mother's character or past conduct rendered her unfit in the court's opinion to have such custody, that preference would be given to the father. In the case of adolescent boys, however, the courts have

and lesbian community as and when aspects of their relationships are found to be prejudiced by unconstitutional legislation. Where a statute is challenged on the ground of unfair discrimination against gays and lesbians on the grounds of their sexual orientation, difficult questions arise in relation to the determination of the particular relationships entitled to protection, and the appropriate relief. The precise parameters of relationships entitled to constitutional protection will often depend on the purpose of the statute. It is not appropriate for courts to determine the details of the relationship between partners to same-sex, or for that matter heterosexual partnerships. It is also not for the courts to work out the details of the relationship between any such partners and their children. In casu the court has not heard any argument and has not considered the respective duties which might arise between the applicants in respect of the children. These are matters for the legislature to consider. See too National Coalition for Gay \& Lesbian Equality v Minister of Home Affairs 20002 SA 1 (CC); Satchwell $v$ President of the Republic of South Africa 20026 SA 1 (CC).

70 In Dunsterville $v$ Dunsterville 1966 NPD 594 it was held that:

[e]perience goes to show that a child needs both a father and a mother, and that, if he grows up without either he will, to some extent, be psychologically handicapped. But the maternal link is forged earlier in the child's life than the paternal, and if not forged early may never be forged at all. 
shown greater readiness to award custody to the father, other factors being equally in favour of both parents.

The 'maternal preference' or 'tender years' principle can be seen as violating the equality clause in section 9 of the Constitution by discriminating between parents on the basis of gender. Judicial awareness of all forms of chauvinism and sexism, the striving for equality between the sexes, and current changes (both nationally and internationally) in the traditional roles of parents and spouses, lead to value systems and societal beliefs underpinning the maternal preference principle being challenged. ${ }^{72}$

In Van der Linde $v$ Van der Linde ${ }^{73}$ the court deviated from a previous exposition of the common law which advanced the maternal preference principle. The court held that for decades it has been accepted that the quality of a parental role is determined by gender and further that mothering was a component of a woman's being only. At the present juncture it is to be doubted whether that acceptance can still be accepted as a universally prevailing axiom. The concept 'mothering' is indicative of a function rather than a persona and this function is not necessarily situated in the biological mother. It includes the sensitive attachment which flows from the attention devoted to the child's needs of love, physical care, nutrition, comfort, peace, security, encouragement and support. Only the parent who can satisfy this need will succeed in forging a psychological bond with the child and it is in this parent's care where the child can experience his existence as having meaning and in which he will be sheltered and protected with affection. Mothering assumes the showing of unconditional love without necessarily expecting anything in return. Mothering is a component not only of the woman's, but also of the man's being. In the past, society expected men to suppress that part of their personality because it did not fit the image of the man. Today the man has the freedom to reveal and live out his mothering feeling. A father can be

71 In Manning v Manning 19754 SA 659 (T) the Court explains that

[t]here comes a time ... especially in the case of boys, when, all other things being equal, they require the care and guidance of their father more than of their mother; this is especially the case when the boy is approaching the age of puberty.'

72 Van Heerden et al. Boberg's Law of Persons and the Family 538.

7319963 SA $509(0)$. 
just as good a mother as the biological mother and naturally a mother can be just as good a father as the biological father. The quality of a parental role is not determined by gender.

In Van Pletzen $v$ Van Pletzen ${ }^{74}$ the court relied squarely on Van der Linde and concluded that the assumption that the mother is better able than the father to care for a child belongs to an era of the past. It reiterated the acceptance that mothering is not only a component of a woman's being, but is also part of a man's being and that a father, depending on the circumstances, possesses the capacity and capability to exercise custody over a child as well as the mother.

A more cautious approach was signalled, however, in Ex parte Critchfield. ${ }^{75}$ Pointing out that maternal preference is nowhere pertinently stated in the list of factors in McCall, the court concluded that, given the fact of the dynamics of pregnancy, it would not amount to unfair discrimination in the sense that it would be unconstitutional for a court to have regard to maternity as a fact in making a determination as to the custody of young children. However, it would amount to unfair discrimination, and it would correspondingly be unconstitutional, if a court were to place undue weight upon this factor when balancing it against other relevant factors. In fact, the court conveys that the only significance of the Constitution with regard to custody disputes is that the court must be astute to remind itself that maternity can never be, willy nilly, the only consideration of any importance in determining the custody of young children.

In terms of section 28 of the Constitution, the best interests of the child remain the paramount consideration. Consequently, if a father can better provide what the court considers to be in the best interests of the child, he will be the

7419984 SA $95(\mathrm{O})$.

7519993 SA $132(\mathrm{~W})$.

76 A similar approach was voiced in President of the

Republic of South Africa v Hugo 19974 SA 1 (CC) where the Court held that

[I] ... see no reason to doubt that, as a matter of fact in South African society, mothers not only bear a considerably greater proportion of the burdens of child rearing than fathers, but also that mothers, as a general rule, have a special role in relation to the nurturing and care of children. 
proper person to be awarded custody of the child. Similarly, if the mother is better equipped, she should be awarded custody. With regard to the biological basis for differentiation, it can only apply to the position of very young children in respect of whom 'the support and succour' given by the mother to the infant could be said to be 'very direct and not comparable to that of a father.'

\section{The child's preference}

One of the factors mentioned in McCall that the court should take into account is the child's preference if the court is satisfied that in the particular circumstances it should be taken into consideration. This approach corresponds with article 12 of the Convention on the Rights of the Child 1989 which provides that States Parties to the Convention shall assure to the child who is capable of forming his or her own views the right to express those views freely in all matters affecting him or her. Such views are to be given due weight in accordance with the age and maturity of the child. If the court is satisfied that the child has the requisite intellectual and emotional maturity to express a genuine and accurate reflection of his or her feelings towards, and relationship with, each of the parents, in other words to make an informed and intelligent judgment, weight should be given to such expressed preference.

In establishing the child's ability to make an informed and intelligent judgment, the subjective views of courts are sometimes found to influence their assessment. From Oppel $v$ Oppel ${ }^{79}$ and Mathews $v$ Mathews $^{80}$ it appears that the courts were inclined to consider the age, rather than maturity of the child, as the deciding factor. In Greenshields $v$ Wyllie ${ }^{81}$ the court, after acknowledging that children are 'human beings and having personalities of

See also Madiehe (born Ratlhogo) v Madiehe [1997] 2 All SA 153 (B).

77 In Madiehe the court cautions that custody of a young child is a responsibility as well as a privilege and that it is not a gender privilege or a right.

78 McCall supra $\mathrm{n} 59$ at $207 \mathrm{H}-\mathrm{I}$.

791973 S SA $675(\mathrm{~T})$. In this case it was held that a girl of eight years old was too young to express a view with regard to access. See too Germani v Herf 19754 SA 887 (A).

8019834 SA 136 (SE). The Court held that the views of a 13 year old may not carry much weight, but where a 17 year old girl expresses a wish, it is a factor which must be given serious consideration.

8119894 SA $898(W)$. 
their own, having emotional preferences of their own, being normal', made the following observation:

At the age of 12 and 14 it is particularly difficult to know who you are and where you are going and where you belong. Everyone knows that. I may add that I have four daughters. It is understandable that they may resent certain things, that they may dislike certain things, that they may not like ... or at times even their mother or grandmother and at times not even their best boy friend. That is normal. But the court also knows that as time goes by, their own perspective changes. It is then that they long for having both the father and the mother; it is then that they regret not having built up a good relationship. ... For those reasons, because the Courts know that children grow up, that their perspectives change, that their needs change, a court is not inclined to give much weight to the preferences of children of 12 and 14 . It is not because what they say is not important but because the Courts know that there is more to it than the way they respond emotionally at this stage.

A different approach was followed in Märtens $v$ Märtens, ${ }_{84}^{82}$ McCall ${ }^{83}$ and Meyer $v$ Gerber. From these cases it becomes evident that the courts are inclined to take the maturity of the child into account, rather than its age. In the Meyer case, the court was satisfied that the 15 year old son of the parties was endowed with enough emotional and intellectual maturity to have made a calculated and intelligent decision and that due weight should be attached to his stated preference and choice. The boy's position was not something which had become established overnight. It was not an emotionally uninformed and

8219914 SA $287(\mathrm{~T})$. The court considered it necessary to see and speak to the children, twins aged 11 years, personally. It found that they were both attractive, talented and intelligent children who, though lacking in maturity because of their youthfulness, were able to speak their minds spontaneously and with as much confidence as they could muster under the circumstances.

83 Supra $n$ 63. In casu the court had a talk tête-á-tête with a 12 year old boy. The court found that the preference to stay with the father was conveyed explicitly and positively by an intelligent, articulate, persuasive, sincere and candid child who displayed a degree of maturity and intellectual development that satisfied the court that he was capable of forming and expressing an intelligent and informed judgment of what he subjectively believed to be in his best interests. 
irrational expression of frustrations or worries but it bore the stamp of an important decision about which he had thought for a long while and in which he had conducted himself as a mature and responsible young man.

85

\section{(ii) The extra-marital child and his or her father}

Extra-marital birth results in certain limitations being placed on specifically the father's rights and duties towards the child. The phrase een wijf maakt geen bastaard in essence still provides the philosophy on which the legal relationship between a child born out of wedlock and his or her parents is based. Recent legislation has done much to improve the legal position of extra-marital children, but some differences with regard to that of legitimate children are still in place.

With regard to guardianship, the guardian of a child born out of wedlock is the mother of the child. The Guardianship Act 192 of 1993 left this common law position unchanged. The Children's Status Act 82 of 1987 provides that where the mother is a minor and not married, the guardian of the mother is also the guardian of the child born out of wedlock. However, as soon as the minor mother attains majority status by getting married or by an order of court, she will become the guardian of the child.

The natural father of a child born out of wedlock may apply to the High Court for an order granting him guardianship or custody of, or access to such child. The Natural Fathers of Children born out of Wedlock Act 86 of 1997

8419993 SA $550(0)$. In this case the court refrained from talking to the parties' 15 year old son personally because the child had made a decision and had persisted therein. The court was prepared however, to take the boy's preferences into account.

85 The machinery is in place to ascertain the preferences of children whenever it is deemed necessary or desirable. In terms of the Mediation in Certain Divorce Matters Act 24 of 1987 and the regulations promulgated there under, the Family Advocate is able to canvass the genuine wishes of the child. With their experience and expertise in safeguarding the interests of minor children, they are ideally placed to establish the reliability of the preferences of children. The court, furthermore, has the power in terms of $s$ of the Divorce Act 70 of 1979 to appoint a legal practitioner to represent a child of the marriage at the proceedings. It may order the parties or any one of them to pay the costs of the representation. In hotly disputed custody, guardianship or access cases, however, there will often be a conflict of interest between at least one of the parents and child concerned. For this reason, the court may well have to have recourse to the provisions of $s$ 28(1)(h) of the Constitution and have a legal practitioner assigned to the child by the State, if necessary at State expense, if substantial injustice would otherwise result. See text accompanying n 110 infra. 
prescribes the conditions for such applications. First and foremost the court has to be satisfied that the application will serve the best interests of the child. It is also required that the court shall consider the report and recommendations of the Family Advocate. The factors to be considered include the following:

- the relationship between the applicant and the natural mother and, in particular, whether either party has a history of violence against, or abuse of, the other or the child;

- $\quad$ the relationship of the child with the applicant and the mother or with proposed adoptive parents (if any) or any other person;

- $\quad$ the effect that separating the child from the applicant or the natural mother or any other person is likely to have on the child;

- the attitude of the child in relation to the granting of the application;

- $\quad$ the degree of commitment that the applicant has shown towards the child;

- $\quad$ whether the child was born of a customary union according to indigenous law or custom or of a marriage concluded under a system of any religious law; and

- $\quad$ any other fact that, in the opinion of the court, should be taken into account.

Previously, only the mother as guardian of an extra-marital child had to consent to the child's adoption. To improve the position in which the fathers of such children found themselves, the Child Care Act has been amended so that the consent of both the mother and the natural father is now required for adoption, provided the father acknowledges in writing that he is the father of the child and that he has made his identity and whereabouts known. 
The common law position with regard to access was simply that the father, not being endowed with parental authority over the child, had no access to the child. It has often been conceded, however, that the court may grant reasonable access to the father if it would be in the interest of the child. The remedy was not granted lightly and additional requirements had to be met to satisfy the best interests principle. Against this background the Natural Fathers of Children born out of Wedlock Act comes as a relief. This Act does not give the natural fathers of such children an automatic right of access; it does define the procedure to be followed by these fathers in applying to the High Court for access rights to their children.

\section{Socio-economic rights of the child}

28(1) Every child has the right -

(c) to basic nutrition, shelter, basic health care services and social services;

Along with the introduction of the new constitutional dispensation, the concept of social security was introduced. Various socio-economic rights pertaining to 'everyone' were included in the Bill of rights, while the right to basic nutrition, shelter, basic health care services and social services specifically relates to children. In a sense this right gives qualitative content to the child's right to family, parental or alternative care. It provides the base-line goods a child is entitled to receive as components of that care. It is interesting to note that, on the one hand, this section provides for entitlement to a more expansive range of goods and services than a child would be entitled to in terms of sections 26 and 27 . These sections provide for the right of everyone to access to housing, adequate food and water, medical services and social security and assistance. On the other hand, however, children's socio-economic rights are intended to guarantee for children a certain basic subsistence level of the same social and economic aspects that are provided for in more advanced form in sections 26 and 27 . Therefore, section 26(1) guarantees the right of

86 See too Davel Introduction to Child Law in South Africa 33-39; Davel \& Jordaan Law of Persons 107113. 
everyone (and therefore also of children) to access to adequate housing, whereas section 28(1)(c) guarantees the right of children only to shelter; section 27(1)(b) guarantees the right of everyone to sufficient food and water, whereas section 28(1)(c) proclaims the right of children only to basic nutrition. The benefits to which a child is entitled in terms of section 28(1)(c) are thus of a narrower level than those they are entitled to in terms of sections 26 and 27 . They are regarded as the very minimum a child requires in order to subsist, whereas the entitlements in terms of everyone's socioeconomic rights set the levels required for a person to live a full and dignified life.

Furthermore, the entitlements of a child in terms of section 28(1)(c), as opposed to the entitlements of a child and everyone in sections 26(1) and 27(1) are unqualified with respect to the availability of resources. Sections 26(1) and 27(1) are both qualified in the duties they impose by sections 26(2) and 27(2) respectively in that both subsections read that the State must take reasonable legislative and other measures, within its available resources, to achieve the progressive realisation of the particular rights. This means that the duties to provide access to housing, health care services, food and water and social security and assistance implied by these provisions have to be met by the State only progressively by means of reasonable legislative and other measures and within available resources. Section 28(1)(c) prima facie is not qualified by a similar provision. As discussed in note 88 infra, the Constitutional Court decided differently, holding that by interpreting section $28(1)(c)$ as unqualified, children could become stepping stones for their parents instead of being valued for who they are.

In the final instance, the entitlements to food, water, housing, health care services and social security guaranteed by sections 26 and 27 are access entitlements - indirect entitlements to the creation of an environment within which people who are reasonably self-sufficient can access the goods in question themselves, rather than being provided with those goods up-front. The entitlements to basic nutrition, shelter, basic health care services and 


\section{social services of section 28 , on the other hand, are direct entitlements to the provision} of the goods in question on demand.

88 Bekink \& Brand (n 26) 188. In Grootboom there were in essence two questions before the court. In housing, thereby imposing an obligation upon the State to take reasonable legislative and other measuresto ensure the progressive realisation of this right within its available resources. In the second place it was contended that s 28(1)(c) entitled all the applicants, including those adults without children, to shelter and that the children's unqualified right to shelter placed the right of children to that minimum obligation beyond doubt. The facts of the Grootboom case were briefly as follows: The applicants, including a number of children, had moved onto private land from an informal settlement owing to the 'appalling conditions' in which they were living. They were evicted from the private land that they were unlawfully occupying. Following the eviction, they camped on a sports field in the area. However, they could not erect adequate shelters as most of their building materials had been destroyed during the eviction. They applied to the High Court for an order requiring Government to provide them with adequate basic shelter or housing until they obtained permanent accommodation. In an affidavit one of the litigants describes the conditions as follows:

My family and I lived with my sister and her husband who have three children. We lived in a small shack which was approximately 20 square metres in size. The living conditions for me and my common law husband and our child became increasingly unsatisfactory in that the limited space which we had, allowed for no privacy. The further applicants, as far as I have personal knowledge in that regard, lived with their extended families and in many instances there were three to four families living in structures similar to the one of my sister. Certain applicants lived in an area in Wallacedene that had a water table problem resulting in the areas around such structures always being waterlogged. The situation was not suitable for the health of them and their children and asthma, flu and other illnesses were common in the area. The High Court dealt with the argument relating to $s$ 26 first. Following the decision in Soobramoney v Minister of Health, Kwa-Zulu Natal 19981 SA 765 (CC) the court cautions against an excessively generous approach to these rights. It also reiterates that a court will be slow to interfere with rational decisions taken in good faith by political organs and medical authorities who deal with these matters. In view of the evidence placed before the court that a rational housing programme had been initiated at all levels of government and that the programme had been designed to solve the pressing problem in the context of scarce financial resources, the court refused to accept the argument pertaining to $s 26$. In relation to $s$ 28(1)(c), the court was referred to the dictionary meaning of shelter where it is set out as '[a] structure affording protection from rain, wind or sun; any screen or place of refuge from the weather. A place of temporary lodging for the homeless poor.' The court concludes, therefore, that $s$ 28(1)(c) provides for a right to be protected from the elements in circumstances where there is no need to remove a child from its parents. The primary obligation to maintain a child rests upon the parents. Such an obligation includes the provision of shelter. In the event where parents are unable to provide shelter for the children, s 28(1)(c) imposes an obligation on the State to do so, albeit that by the use of the word shelter the Constitution envisaged that such obligation falls short of adequate housing. The court furthermore conveys that from the dictionary definition of shelter, it must be accepted that it reflects a significantly more rudimentary form of protection from the elements than is provided by a house. However, a further question concerns the provision of shelter for the parents. The link between parent and child could be applied to argue for a different approach to s 28(1)(c). The court emphasises that the child is the bearer of the right in terms of $s$ 28(1)(c). In casu the applicants argued that reading $s$ 28(1)(b) with $s$ 28(1)(c) justified the creation of a derivative right, namely one possessed by the parents. As the family must be maintained as a unit, parents of the children who are granted shelter should also be entitled to such shelter. This means that the bearer of the right now becomes the family. The justification for such a conclusion is that a failure to recognise the parents would prevent the children from remaining within the family fabric. This would penalise the children and indeed the parents who, to a considerable extent owing to the ravages of apartheid, are unable to provide adequate shelter for their own children. The court points out that there is understandable concern that this interpretation of $s$ 28(1)(c) could be used by parents to obtain access to housing which would otherwise be denied on the basis of the interpretation of s 26 . It must be understood, the court explains, that s 28(1)(c) only envisages the concept of contemporary shelter. The provision of shelter to the children should therefore be of such nature that the parents may join them. This does not mean, however, that the parents become the bearers of a constitutional right which expressly provides that children have such right. An order which enforces a child's right to shelter must therefore take account of the need of a child to be accompanied by his or her parent. Such approach would be in accordance with the spirit and purport of $s 28$ as a whole. Furthermore, the court conveys that the question of budgetary limitations is not applicable to the determination of rights in terms of $s 28(1)(c)$. The argument that the right to shelter, even temporary shelter, would have a dramatic impact on the budget in as much as all persons with children would be able to enforce this right on demand was rejected by the court. This right of children has not been made subject to qualifications of availability of financial resources. The court therefore concludes that a parsimonious interpretation of $s$ 28(1)(c) would deny shelter to the infant children of the applicants. This result would be incongruent with a constitutional instrument which envisages the establishment of a society based on freedom, equality and dignity. 
To implement the right in this case so that shelter will be provided for the children in circumstances where they will be denied the psychological comfort and social support of their parents, would be to permit the break up of family life of a kind which the Constitution is determined to prevent. This decision came before the Constitutional Court by way of appeal. (See Government of the RSA v Grootboom 20011 SA 46 (CC)). The Constitutional Court also dealt with the interpretation of ss 26(1) and 28(1)(c). However, it first dealt with the justiciability of socioeconomic rights in the South African Constitution. It referred to the decision of the Constitutional Court in the first Certification judgment (supra $n$ 1) where the court held as follows: (T)hese rights are, at least to some extent, justiciable. As we have stated in the previous paragraph, many of the civil and political rights entrenched in the [constitutional text before this Court for certification in that case] will give rise to similar budgetary implications without compromising their justiciability. The fact that socio-economic rights will almost inevitably give rise to such implications does not seem to us to be a bar to their justiciability. At the very minimum, socioeconomic rights can be negatively protected from improper invasion. In view of the fact that $s 7(2)$ of the Constitution requires the State to respect, protect, promote and fulfil the rights in the Bill and that the courts are constitutionally bound to ensure that they are protected and fulfilled, the question is not whether such rights are justiciable, but rather how to enforce them in a given case. The court explains that this is a difficult issue which must be explored on a case-by-case basis. Against this background the court considers the method of interpretation of the provisions of $s 26$ to establish the true meaning of the section. Like all other rights in the Bill, s 26 must be construed in its context. This requires the consideration of two types of context. On the one hand, rights must be understood in their textual setting. This requires a consideration of the Bill and the Constitution as a whole. On the other hand, rights must also be understood in their social and historical context. All the rights in the Bill are inter-related and mutually supporting. Against this background there can be no doubt that human dignity, freedom and equality, the foundational values of our society, are denied those who have no food, clothing or shelter. Affording socio-economic rights to all people therefore enables them to enjoy the other rights enshrined in the Bill. It is clear that the right of access to adequate housing cannot be seen in isolation. There is a close relationship between it and the other socio-economic rights. Socio-economic rights must all be read together in the setting of the Constitution as a whole. The State is obliged to take positive action to meet the needs of those living in extreme conditions of poverty, homelessness or intolerable housing. Their interconnectedness needs to be taken into account in interpreting the social economic rights, and, in particular, in determining whether the State has met its obligations in terms of them. This analysis serves as point of departure to establish whether the State has taken reasonable legislative and other measures bearing in mind that the State is under an obligation to progressively realise this right within its available resources. $S$ 26(2) clearly does not impose an unqualified obligation on the State. The Constitutional Court rejects the approach of the court a quo that the State must provide rudimentary shelter irrespective of the availability of resources on the basis that this reasoning produces an anomalous result. People who have children would have a direct and enforceable right to housing under s 28(1)(c) while others who have none, or whose children are adult, no matter how old, disabled or otherwise deserving they may be, would not be entitled to housing under this section. The carefully constructed constitutional scheme for progressive realisation of socio-economic rights would make little sense if it could be trumped in every case by the rights of children to get shelter from the State on demand. Moreover, the court warns that there is an obvious danger - children could become stepping stones to housing for their parents instead of being valued for who they are. The court also rejects the decision of the court a quo that the Constitution draws a distinction between housing on the one hand and shelter on the other, and that shelter is a rudimentary form of housing. Housing and shelter are related concepts and one of the aims of housing is to provide physical shelter. But shelter is not a commodity separate from housing. While it is true that all shelter represents protection from the elements and possibly even from danger, there is a range of ways in which shelter may be constituted. Shelter may be ineffective or rudimentary at the one extreme and very effective and even ideal on the other. The concept of shelter in s 28(1)(c) is not qualified by any requirement that it should be 'basic' shelter. The Constitution does not limit the concept of shelter to basic shelter alone. The concept of shelter in the subsection embraces shelter in all its manifestations. However, it does not follow that the Constitution obliges the State to provide shelter at the most effective or the most rudimentary level to children in the company of their parents. The true nature of the obligation created by $s 28(1)(c)$ can only properly be ascertained in the context of the rights created by other socio-economic provisions in the Bill. These provisions in ss 26 and 27 expressly oblige the State to take reasonable legislative and other measures within its available resources to achieve the rights with which they are concerned. It is so that there is an overlap between these provisions and that of $s$ 28(1)(c). Apart from this overlap, these provisions are conferred on everyone, including children, while s 28 accords rights only to children. This overlap is not consistent with the notion that $s$ 28(1)(c) creates separate and independent rights for children and their parents. The court concludes, therefore, that the true nature of s 28(1)(c) can only be established if it is read in conjunction with $s$ 28(1)(b). To ensure that children are properly cared for by their parents or families, and that they receive appropriate alternative care in the absence of parental or family care, is clearly the aim of these subsections. It follows from s 28(1)(c) that the Constitution contemplates that a child has a right to parental or family care in the first place, and a right to alternative appropriate care only where that is lacking. Through legislation and the common law, the obligation to provide shelter is imposed primarily on parents or family and only alternatively on the State. The State thus incurs the obligation to provide shelter to those children, for example, who are removed from their families. The right of a child to shelter does not create a primary State obligation to provide shelter on demand to parents and their children if children are being cared for by their parents or families. This 
exposition does not mean, however, that the State incurs no obligation in relation to children who are being cared for by their parents or families. In the first place, the State must provide a legal and administrative infrastructure necessary to ensure that children are accorded the protection contemplated by $s 28$. This obligation would normally be fulfilled by passing laws and creating enforcement mechanisms for the maintenance of children, their protection from maltreatment, abuse, neglect or degradation. In addition, the State is required to fulfil its obligations to provide families with access to land, adequate housing, and to health care, food, water and social security. These rights require the State to provide access on a programmatic and co-ordinated basis. They are, however, subject to available resources. One of the ways in which the State would meet its obligation to provide social security, would be through a social welfare programme providing maintenance grants and other material assistance to families in need in defined circumstances. 
28(1)(d) Every child has the right -

(d) to be protected from maltreatment, neglect, abuse or degradation;

The right to family, parental and alternative care emphasises the importance of the family and parents in meeting the needs of children. However, the old adage that 'every (English-)man's home is his castle' has been recognised as often being detrimental to the well-being of children. Unemployment, poverty, illiteracy, addiction, criminality and family breakdown compound in serious abuses of children, often in their own home. This right of children therefore imposes a duty on private persons as well as the State to refrain from these forms of treatment. In addition, it requires primarily of the State to act positively to prevent abuse, maltreatment, neglect or degradation. The obligation of the State is to intervene in situations of ongoing maltreatment, abuse, neglect and degradation in the family or another context by, for instance, removing the child from that situation. In this instance the State is required to act positively to stop ongoing 90 abuse. This duty is to

89 See Bekink \& Brand (n 26) 188; De Waal et al (n 1) 464; Van der Vyver (n 3) 306.

90 Various statutory provisions, pre- and post the Constitution, serve as examples of legislative attempts to deal with the neglect, abuse or degradation of children. S 50 of the Child Care Act 74 of 1983 makes itan offence to ill-treat a child or allow it to be ill-treated. It also makes it an offence to abandon a child. The Sexual Offences Act 23 of 1957 contains various provisions that criminalise sexual intercourse with minors. S 9 provides that any person who, being a parent or guardian of a child under the age of 18 years, permits, procures or attempts to procure such child to have unlawful carnal intercourse, or to commit any immoral or indecent act, with any person other than the procurer, or to reside in, or frequent a brothel; or who orders, permits or in any way assists in bringing about, or receives any consideration for, the defilement, seduction or prostitution of such child shall be guilty of an offence. A parent or guardian charged with contravention of this section is deemed to have knowingly permitted his or her child to consort with, or to continue in the employment of, a prostitute or a person with an immoral reputation. See also ss 12 and 14. In terms of the last mentioned section a male person who has, or attempts to have unlawful carnal intercourse with a girl under the age of 16 years, or who commits or attempts to commit an immoral or indecent act with such a girl or a boy under the age of 19 years, is guilty of an offence. In addition, s 50 of the Child Care Act places an obligation on owners, occupiers, tenants, lessors and managers of buildings wherein the sexual exploitation takes place to report such incidents to the police. In terms of $s$ 42(1) the Child Care Act an obligation is placed on dentists, medical practitioners, nurses and social workers to report child abuse. Initially the reach of this provision was limited in that it restricted the responsibility for reporting child abuse to specific health professionals and social workers. It excluded other professionals who would come into 
some extent given legislative effect by the Child Care Act which empowers police officers, social workers and other authorised persons to remove children from their homes and take them to a place of safety under certain circumstances. ${ }^{91}$ Certain criteria are provided for by the Act for decisions to remove children from their families.

\author{
Section 294 of the Criminal Procedure Act 51 of 1977 initially provided for corporal \\ punishment also for juvenile delinquents. This provision, however, was declared \\ unconstitutional on the basis that it was cruel, inhuman and degrading in $S v$ Williams. \\ Following this decision, Parliament passed the
}

contact with children such as teachers, day care workers and the clergy. Therefore, in terms of an amendment in 1996, teachers and 'any person employed by or managing a children's home, place of care or shelter' are now also legally obliged to report child abuse.

91 Bekink \& Brand (n 26) 189 correctly point out that the State, in meeting this positive duty to intervene in situations of ongoing abuse to protect a child, acts in conflict with a child's right to family or parental care. This creates the need for a flexible test against which to decide whether a decision by a relevant government official to intervene or not to intervene in a situation of abuse is constitutionally sound. A State actor must exercise reasonable professional judgment in conducting the investigation into the alleged abuse and in the decision to act or not to act after the investigation.

92 These criteria are set out as follows in s 14:

[t]he children's court shall determine whether -

(a) the child has no parent or guardian; or (aA) the child has a parent or guardian who cannot be traced; or

(b) the child has a parent or guardian or is in the custody of a person who is unable or unfit to have the custody of the child in that he -

is mentally ill to such a degree that he is unable to provide for the physical, mental or social well-being of the child;

has assaulted or ill-treated the child or allowed him to be assaulted or ill-treated;

has caused or conduced to the seduction, abduction or prostitution of the child or the commission by the child of immoral acts;

displays habits and behaviour which may seriously injure the physical, mental or social well-being of the child;

fails to maintain the child adequately;

neglects the child or allows him to be neglected;

cannot control the child properly so as to ensure proper behaviour such as regular school attendance;

has abandoned the child; or has no visible means of support.

9319953 SA 632 (CC). The court in casu held that no compelling interest has been proved to justify

the practice of corporal punishment. It also found that its effect is likely to be coarsening and degrading rather than rehabilitative. Juvenile whipping, according to the court is cruel, inhuman and degrading and it cannot be justified in terms of the Constitution. In Christian Education South Africa v Minister of Education 20004 SA 757 (CC) it was decided that the prohibition of corporal punishment was a justifiable limitation of the right to freedom of religion. In this case the applicant was a voluntary association representing 196 independent schools with approximately 14500 learners. The constituent schools maintained an active 


\begin{abstract}
Abolition of Corporal Punishment Act 33 of 1997. It remained uncertain, however, to what extent corporal punishment in schools and the home was constitutional. In Christian Education South Africa $v$ Minister of Education, ${ }^{94}$ however, the court found that a provision in the South African Schools Act 84 of 1996 which abolished corporal punishment in schools was a justifiable limitation of the right to freedom of religion.
\end{abstract}

\title{
Economic rights of the child
}

S 28(1) Every child has the right -

(e) to be protected from exploitative labour practices;

(f) not to be required or permitted to perform work or provide services that -

(i) are inappropriate for a person of that child's age; or

Christian ethos by providing a learning environment in which the learners could be educated in keeping with their Christian religion. The applicant challenged the constitutionality of the South African Schools Act 84 of 1996. It sought to have the Act declared unconstitutional and invalid to the extent that it was applicable to the independent schools whose parents or guardians have consented to corporal punishment being imposed. The court decided that the constitutional right of persons belonging to cultural or religious communities to enjoy their culture and to practice their religion could not be used to shield practices which offended the Bill of Rights. Assuming that corporal punishment as practised by applicant's members was not inconsistent with the provisions of the Bill, these provisions of the Schools Act limited the religious rights of parents. The question, therefore, was whether this limitation could be justified in terms of s 36 of the Constitution. In this regard the court explains that limitations on constitutional rights can only pass constitutional muster if it can be concluded that, considering the nature and importance of the right and the extent to which it is limited, such limitation is justified in relation to the purpose, importance and effect of the provision which resulted in the limitation taking into account the availability of less restrictive means to achieve the relevant purpose. What was at issue, therefore, was whether the impact of the prohibition on the religious beliefs and practices of the members of applicant could be justified under the limitations test of $s 36$. The proportionality exercise had to relate to whether the failure to accommodate applicant's religious belief and practice by means of exemption could be accepted as reasonable and justifiable in an open and democratic society based on human dignity, freedom and equality. The court emphasised that while parents could no longer authorise teachers to apply corporal punishment in their name pursuant to their beliefs, they were not deprived by the Schools Act of their general right and capacity to bring up their children according to their Christian beliefs. Furthermore, the State is under a constitutional duty to take steps to help diminish the amount of public and private violence in society generally and to protect all people and especially children from maltreatment, abuse or degradation. The outlawing of physical punishment in the school had a principled and symbolic function manifestly intended to promote respect for the dignity and physical and emotional integrity of all children.

9419999 BCLR 951 (SE). 
(ii) place at risk the child's well-being, education, physical or mental health or spiritual, moral or social development.

The protection of the right of children in this regard serves as recognition of the fact that child labour is an acutely experienced phenomenon in the South African community. Subsection (e) creates a positive obligation for the State to protect children against exploitative labour practices from other actors in society. Subsection (f) on the other hand imposes a negative duty in the vertical and horizontal relationship (thus also against private actors) to desist from engaging children in exploitative labour practices.

From the wording of this article, it is clear that neither of these subsections imposes an 97 absolute ban on child labour. It recognises the fact that thousands of children are engaged in paid labour of some kind and that the lives of such children, and in many instances that of their families, depend on their ability to earn an income in this way. The duty to protect children against

95 Findings of a survey done by the South African Department of Labour in 1999 include the following: $36 \%$ (4.8 million) of South Africa's 13.4 million children were doing at least three hours of economic work a week and/or five hours or more per week of school related work, and/or a seven hours or more of household chores; With a cut-off of 12 hours of economic activities per week, 14 hours of household chores and 12 hours of school labour, 12,5\% (1.7 million) of children in South Africa were doing work;

Of the children engaged in economic activities for three hours per week or more, 59\% said they were working because they had a duty to help their family, and a further $15 \%$ said they worked to assist the family with money;

Of those in agriculture, many were working in subsistence agriculture, on family farms, rather than as paid employees;

Children aged 5-14 years who appear to be working in contravention of the law account for at least $30 \%$ of the working children concerned;

Of the children engaged in a narrowly-defined economic work for three hours or more, $61 \%$ indicated that they were exposed to hazardous conditions, $2 \%$ conveyed that they have suffered illness related to the work and $4 \%$ that they had been injured at work.

96 Bekink \& Brand (n 26) 190.

97 Socio-economic conditions in South Africa are often such that the income earned by a child, sometimes even of tender years, may be an essential, even the only, source of maintenance of a family. The constitutional right of the child not to be required or permitted to provide services that are inappropriate for a person of that child's age, therefore also impacts on the duty of the State to provide social security. Such would include appropriate social assistance to persons and families unable to support themselves and their dependants. This duty would require the State to take reasonable measures, within its available resources, towards that end. In circumstances of ultimate need, where for the sake of survival recourse 
exploitative labour practices also does not require an absolute ban. What is required, is that the State takes measures to protect children against exploitation in the labour environment. The kind of exploitation a child is to be protected against, is in terms of subsection ( $f$ ) exploitation caused by a child being required to do work that is inappropriate to its age and puts its wellbeing, education, physical or mental health or spiritual, moral or social development at risk. 98

\section{Rights of the child in the administration of justice}

28(1) Every child has the right -

(g) not to be detained except as a measure of last resort, in which case, in addition to the rights a child enjoys under ss 12 and 35, the child may be detained only for the shortest appropriate period of time, and has the right to be -

(i) kept separately from detained persons over the age of 18 years; and

has to be taken to child labour, the duty of the State becomes particularly compelling. See Van der Vyver (n 3) 307. See too n 47 supra.

98 ibid. The current legislative framework for child labour is provided by s 52A of the Child Care Act

and s 43 of the Basic Conditions of Employment Act 75 of 1997 which took effect in March 1999. The last mentioned Act is the more important one as it deals explicitly with child work. It prohibits employment of a child who is under 15 years old; who is under the minimum school leaving age (where this age is 15 years or older); who is over 15 years but under 18 years old, if the employment \& is inappropriate for the age of the child or if the work places at risk the child's wellbeing, education, physical or mental health, or spiritual, moral or social development; $\&$ has been prohibited by the Minister of Labour through regulations. A person is considered an employee if that person

works for another person and receives remuneration; or in manner assists in carrying on or conducting the business of an employer; and is not an independent contractor. S 52A of the Child Care Act contains a similar prohibition, namely that 'no person may employ or provide work to any child under the age of 15 years.' This clause has wider application than that of the Basic Conditions of Employment Act. It does not only outlaw employment of such children, but also provision of work. It is, for example, likely that this section prohibits giving work to a child who works as an independent contractor. S 46 of the Basic Conditions of Employment Act provides that it is a criminal offence to assist an employer to employ a child in contravention of the Act, and to discriminate against a person who refuses to permit a child to be employed. 
(ii) treated in a manner, and kept in conditions, that take account of the child's age.

A child, like everyone else, is entitled to the due process provisions in the Constitution: the rule against arbitrary arrests; proscription of detention without trial; protection against violence; freedom from torture and from cruel, inhuman and degrading 99 treatment or punishment; and the guarantees of the basic norms of criminal procedure pertaining to persons arrested ${ }^{100}$ in detention ${ }^{101}$ and accused of a criminal offence. ${ }^{102}$ This section specifically, read in conjunction with sections 12 and 35 of the Constitution, is of importance not only for the criminal justice system but also for the Department of Correctional Services. The specific wording of the section conveys that no child should be detained and that any detention of a child indeed constitutes a limitation of the right in itself. ${ }^{103}$ This right of children is qualified, however, since detention of children would be allowed if such detention could be regarded as a measure of last resort. Consequently, if this requirement has been met, it would render the detention of a child constitutionally sound. ${ }^{104}$ It needs to be emphasised, though, that the protection given to children in this sub-section is in addition to the rights which children, like all other people, enjoy under sections 12 and 35 of the Bill. Section 12 guarantees to every person the right to freedom and security of the person. Section 35, on the other hand, affords various rights specifically directed at arrested, detained and accused persons, inclusive of children.

The requirement that the child may only be detained for the shortest appropriate period of time, leaves a measure of doubt what will be regarded

$99 \mathrm{~S} 28(\mathrm{~g})$ read with s $12(1)$ of the Constitution.

$100 \mathrm{~S} 28(\mathrm{~g})$ read with s 35 (2) of the Constitution.

101 S 28(g) read with s 35(2) of the Constitution.

102 Ss $28(\mathrm{~g})$ read with s $35(3)$ of the Constitution.

103 S 36 of the Constitution. See too Bekink \& Brand (n 26) 191; Van der Vyver (n 3) 309.

104 Bekink \& Brand (n 26) 191. The authors convey that the Constitution is vague in this regard and that it does not provide a guide or an answer as to what will be regarded as a measure of last resort. They suggest that it would be safe to say that only if all other possible remedies have been explored and are not appropriate in the specific circumstances, detention can be regarded as a measure of last resort. An objective investigation and evaluation of all the relevant circumstances and factors of each specific case would have to be undertaken and the State will have to explore all other options before detention is finally decided upon.

105 Bekink \& Brand (n 26) 191. 
as the shortest appropriate time. It is suggested, though, that the surrounding circumstances would provide an indication. It would also be for the courts to determine certain minimum standards in this regard. In specific situations, the State carries the onus of satisfying the court that a detention period is necessary in the specific circumstances. Should the State fail in this regard, further detention would be unconstitutional and immediate release would be the most appropriate relief.

When children are detained, whether awaiting trial or after being sentenced, they have the right to be kept separately from other detained persons over the age of 18 years. This protection measure acknowledges that children are more vulnerable than adults to the negative effects of the correctional environment. Special protection should therefore be provided to minimize the contact of children with other hardened criminals. The younger the child, the more vulnerable he or she is and the more strictly separation should enforced. ${ }^{107}$ By keeping children away from adult detainees, the risk of them

106 ibid.

107 Even before the Constitution came into operation, legislative measures had been provided to protect children in detention. S 276 of the Criminal Procedure Act 51 of 1977 provides for 'imaginative sentencing measures' such as house arrest, monitoring, community service and placement in employment. Juveniles may also be given the benefit of other alternative sentences, such as a fine, postponement or suspension of sentence, or caution and the discharge, correctional supervision and converting the trial into an inquiry under the Child Care Act. This Act makes provision for placing the child in the custody of a suitable foster parent; sending the child to a designated children's home; sending a child to a designated school of industries; and returning the child, under supervision of a social worker, to the care of his or her parent or guardian. See Also S v Williams 19953 SA 632 (CC). In S $v$ Blaauw 20013 All SA 588 (C) an example of leniency of the court is to be found. In casu the accused had been convicted of raping a five year old girl. On appeal the court held that the sentence had to fulfil all the objectives of sentencing. However, these objectives had to be applied within the framework of $s 1$ of the Criminal Law Amendment Act 105 of 1997. This section stipulates certain minimum prescribed sentences for certain offences unless the court finds that 'substantial and compelling circumstances' exist to justify a lesser sentence. The Act does not define 'substantial and compelling circumstances'. As the complainant was five years old at the time of the rape, the offence fell within the ambit of $s 51$. In an attempt to establish the existence of substantial and compelling circumstances the court is to find weighty justification to warrant a departure from the rule. The minimum prescribed sentences may not be lightly departed from. If the court is satisfied that the circumstances of the case render the prescribed sentence unjust in that it would be disproportionate to the crime, the criminal and the needs of society, and that an injustice would be done by imposing that sentence, it is entitled to impose a lesser sentence. In the case at hand the accused had committed a serious crime against a defenceless young girl. He also had a bad childhood and a low intelligence level. What was of importance in the view of the court, however, was the fact that the accused was 18 years and six weeks old when he committed the crime. In view of the poor conditions in South African prisons and that life-long incarceration might break the accused physically and emotionally, the court was prepared to accept that even though the 
being negatively influenced or victimized would be avoided to a large extent, which, in turn, could enhance their chances of being rehabilitated.

The requirement that the child in detention should be treated in a manner that takes account of its age, seems to indicate that the younger the child is, the more difficult it would be for the State to provide the basic treatment and conditions that a child of that particular age require. The detention of very young children would therefore seldom, if ever, be constitutionally allowed. 108109

accused was over the age of 18 , his young age was a compelling and substantial circumstance which allowed the court to deviate from the prescribed sentence.

108 Regrettably, there are statistics available indicating that in the period 1998-2003 a total of 74 children between the ages of 7 (inclusive) and 14 (exclusive) were sentenced to prison. Of these, 40 were 13 years old at the time of sentencing, 18 were 12 years old and 16 were between the ages of 7 and 11 . In the same period, 89 children aged 12 were kept in prison awaiting trial, while 36 children between the ages of 7 and 11 were detained in prison while awaiting trial.

109 After ratification of the UN Convention on the Rights of the Child (1989) the South African Law Commission was requested to undertake an investigation into juvenile justice and to make recommendations to the Minister of Justice for the reform of this particular area of law. After a great many workshops and seminars were held to draft a bill on juvenile justice, there is currently a Draft Bill under discussion in which an effort is made to give effect to the provisions of the Constitution. The long title of the Bill describes what is included in the proposed legislation, namely to establish a criminal justice process for children accused of committing offences which aims to protect children's rights as provided for in the Constitution and the UN Convention on the Rights of the Child; to provide for the minimum age of criminal capacity of such children; to describe the powers and duties of police and probation officers in relation to such children; to describe the circumstances in which such children may be detained and to provide for their release from detention; to make a diversion of cases away from formal court procedures a central feature of the process; to establish an individual assessment of each child and a preliminary inquiry as compulsory procedures in the new process; to create special rules for a child justice court; to extend the sentencing options available to such children; to entrench the notion of restorative justice; to provide for legal representation of children in certain circumstances; and to establish an appeal and review procedure as well as an effective monitoring system for the legislation. With regard to criminal capacity, the Bill also contains new provisions. At common law criminal capacity has been determined by the application of two well-known rules derived from Roman law. The first, that a child under the age of seven years is irrebuttably presumed to lack criminal capacity, and is consequently exempt from criminal liability, applies irrespective of the actual maturity, intellectual development or ability of a child below this age to form an intention. In terms of the second rule, a child above the age of seven years but are below the age of 14 years is rebuttably presumed to lack criminal capacity. The burden of 
28 (1) Every child has the right -

(h) to have a legal practitioner assigned to the child by the state, and at state expense, in civil proceedings affecting the child, if substantial injustice would otherwise result;

\section{Section 35(3)(g) provides a right to accused persons in criminal proceedings to legal representation at state expense if substantial injustice would otherwise result. This right applies equally to children as it does to adults. Section 28(1)(h) extends this right to children involved in civil litigation. Section $8 \mathrm{~A}$ of the Child Care Act now provides that a children's court may order that legal representation be provided at state expense for a child involved in proceedings under the Act, if it is in the child's best interest.}

proving beyond reasonable doubt that a child indeed has come full capacity rests on the prosecution in any given case. The prosecution must not only prove that the child was able to distinguish between right and wrong, but also that the child knew that the act was wrongful at the time and in the circumstances in which it was done. The prosecution must further show that the child was capable of controlling his or her conduct in accordance with such knowledge and appreciation. (See Sloth-Nielsen 'Child Justice and Law Reform' in Davel Introduction to Child Law in South Africa 393 et seq.) The Bill repeals the common law with regard to children below the age of 14 years. The minimum age of criminal capacity is raised from seven to 10 years. The rebuttable presumption of doli incapax with regard to children who are at least 10 but not 14 years of age is codified. The Bill provides that

a child who, at the time of the commission of an alleged offence is below the age of 10 years, cannot be prosecuted; and

a child who, at the time of the commission of an alleged offence, is at least 10 years, but not yet 14 years of age is presumed not to have had the capacity to appreciate the difference between right and wrong and act accordingly, but this presumption may be rebutted if it is subsequently proved beyond a reasonable doubt that he or she did have capacity at that time.

The Bill contains elaborate provisions regarding the duties of the police (inter alia to notify the parents of the child) but provides specifically that with regard to serious offences listed in a schedule to the Bill, a police official may not release a child. What will be permissible under these circumstances, though, is that if a place of safety or a secure care facility is available within a reasonable distance from the place where a preliminary enquiry will be held, the child must be detained there in preference to detention in a police cell. This measure is aimed specifically at a concern voiced by some of the commentaries the Law Commission received with regard to combating the high crime rate.

110 This provision unfortunately, has not yet been put into operation. $S 8 A(1)$ provides specifically that a child is entitled to legal representation at any stage of the legal proceedings. S $8 \mathrm{~A}(2)$ requires of the court to inform a child who is capable of understanding, at the commencement of any proceedings, of his or her right to legal representation. See, however, n 85 supra, for a discussion of s 6 of the Divorce Act 70 of 1979, which provides that a court may appoint a legal practitioner to represent a child of the marriage at the divorce proceedings of its parents. 
No indication is given what will constitute substantial injustice. It is suggested, therefore, that all relevant factors and circumstances would have to be taken into account. It is also not clear what the court's role should be in ensuring the contents of this right of children. Should the court, for example, allow a child to refuse legal representation if this would result in substantial injustice? There are no clear answers to these questions but authors submit that the court should at least ensure that a child in legal proceedings, whether criminal or civil, must have been informed of his or her right to legal representation.

28(1) Every child has the right -

(i) not to be used directly in armed conflict, and to be protected in times of armed conflict.

The aim of this subsection is to prevent the recruitment of children into armed forces in time of armed conflict and a direct participation of such children in hostilities. It is to be noted that the age limit of 18 years is in excess of international minimum standards, which in certain instances envisage the recruitment of children older than 15 years into armed forces. $^{111}$ Section 3(1)(b) of the Defence Act 44 of 1957 determines that the minimum age for recruitment into the South African National Defence Force is 17 years. This provision might therefore be in conflict with section 28(h)(i) of the Constitution.

Bekink \& Brand submit that is not clear from the wording of this subsection with the children are also protected against being used indirectly in armed conflict. They suggest, however, that the phrase '[a]nd to be protected in times of armed conflict' would seem to suggest that even such indirect participation would endanger the lives of children and would be constitutionally inappropriate. Nevertheless, this phrase makes it clear that there is an obligation on the State to act positively in this regard. The extent of such protection would be measured against what is reasonable and justifiable

111 Bekink \& Brand (n 26) 193. Art 38(2) of the Convention on the Rights of the Child (1989) provides that states parties to the Convention shall take all feasible measures to ensure that persons who have notattained the age of 15 years do not take a direct part in hostilities. See too De Waal et al (n1) 194. 


\author{
to require from the state in a modern society based on the values of human dignity, \\ freedom and equality. \\ 112
}

112 ibid. The inclusion of this subsection must be viewed against the background of South African youths heavily involved in armed conflict during the struggle against apartheid. In this regard a brief history of the participation of youths in conflict is appropriate. South Africa's recent history is the proverbial tale of two cities, of two people, of two countries. In fact, South Africa's treatment and handling of conflicts in the past was fundamentally determined by skin colour. Black children were the direct victims of the apartheid regime due to their involvement in the politics of liberation. As such, they operated freely and without the regulatory role of the State, and in many cases of the family itself. The price paid for this involvement was a high degree of repression, oppression and alienation. White children on the other hand, experienced a rather protected and secure environment. Under the umbrella of the State and institutions of socialisation such as the church, these children grew up driven by the need to defend the nation from an eminent communist attack. (See Nina Children involved in South Africa's Wars: After Soweto 1976 Published Monograph No 37: Child Soldiers in Southern Africa, April 1999 and the sources referred to there.) The struggle for political freedom created a particular identity for the children of South Africa who participated in the uprising and resistance from 1976. Young black activist became protagonists in a political struggle which forced them into early adulthood. In fact, many children lost their humanity and the capacity to be children after Soweto 1976 . The youth has been at the forefront of struggles since the late 1970s but especially since the mid-1980s. With the call for 'people's war' and the development of 'structures of people's power', youth have created barricades, destroyed the homes of councillors and the councillors themselves, run so-called 'people's courts' and 'manufactured' arms to fight the security forces. However, they also suffered the consequences. The historical role that the children of South African adopted since Soweto 1976, created an identity of resistance, activism and of leadership. In fact, the identity that emerged justified their protagonist role. Moreover, it justified the levels of violence adopted and used against all 'legitimate targets'. The strength of the children/ young people was so powerful that they succeeded in questioning the apparent unchallengeable authority of the State in the late 1970s, and led the process for the 'ungovernability' of the townships in the early 1980s. These politico-military achievements were to be taken seriously. They shaped the identity of children as one of legitimate fighters or warriors that created the popular culture that justified the role of children in the struggle. To fight against apartheid was the right thing to do, no matter what a personal consequences the child needed to endure. The psychological and social damage done by the involvement of children in the struggle, indeed is of a most serious nature. Children have been exposed to violence in many different ways in the country. Stress, trauma, anxiety and depression are obvious sequela to many of the acute or chronic situations which children had to face. However, a further inevitable effect has been that many children or youths have been drawn into an acceptance of 'a culture of violence' as a natural part of daily living and a natural part of the solution to conflict and differences. Apartheid managed to create a culture of brutalisation and repression over children. In fact, since Soweto 1976, State security forces concentrated their energy on repressing children and young people who were considered to be one of the main groups responsible for the lack of stability in the country. Repression and the logical resistance to it, and also the levels of militancy, transformed the psychology of these children and affected the normal process of socialisation. Children and young people became a clear target for the apartheid regime and their normal processes of social regulation were distorted. (The level of brutalisation and repression was so alarming that the New York based Committee for Human Rights defined the apartheid state as one conducting acts of 'terrorism' and engaged in a real 'war against children'. Official figures show that in the 1984-1986 township uprisings, 300 children were killed by police, 1000 were wounded, 11000 were detained and 173000 were held in police cells awaiting trial. Factional fighting in townships and police brutality killed more than 14000 thousand people in the decade stretching from 1984-1994. 


\section{CONCLUSION}

South Africa has experienced enormous political and social change in the last decade. Apartheid has been deposed and democracy has been embraced. There is an increasing recognition of the importance and value of fundamental rights entrenched in both the Constitution and international instruments. Sections 233 of the Constitution which provides that a court must prefer an interpretation of legislation that is consistent with international law, and 39 which requires international law to be considered when interpreting the Bill certainly bear out on this recognition. Section 39(1)(a) reads that a court must promote the values that underlie an open and democratic society based on human dignity, equality and freedom when interpreting the Bill. In the process of such interpretation the court must in terms of section 39(1)(b) consider international law. It is submitted that in the case of children's rights contained in the Constitution, these subsections compel a reading of constitutional provisions in conjunction with provisions of the Convention. This would be the case especially where provisions of the Convention are substantively relevant (ie human rights law). Along this line of argument one can conclude that the basic values that link the genesis of rights and their justifiable limitations, also create an interpretative circle between the Convention and the Constitution. Such interaction between the Convention and the Constitution simultaneously asserts the supremacy of the Constitution and provides a persuasive normative force for the Convention qua international human rights law.

The 'normalisation' of violence and the socialisation through violence have implications also for the Constitution and consolidation of the nation in a post-apartheid society. Violence has come to be expected. The perception that the use of force and violence is the only means of resolving conflict is commonplace. This reflects, and results, in a desensitisation to violence and the loss of respect for human life. See Nina, supra. 